\title{
A full sequence of the Matuyama-Brunhes geomagnetic reversal in the Chiba composite section, Central Japan
}

\author{
Yuki Haneda ${ }^{1,2,3^{*}} \mathbb{D}$, Makoto Okada², Yusuke Suganuma ${ }^{1,4}$ and Takahiro Kitamura ${ }^{2}$
}

\begin{abstract}
Geological records of the Matuyama-Brunhes (M-B) geomagnetic reversal facilitate the development of an age model for sedimentary and volcanic sequences and help decipher the dynamics of the Earth's magnetic field. However, the structure of the geomagnetic field during the $\mathrm{M}-\mathrm{B}$ geomagnetic reversal remains controversial due to its complex field behavior. In this study, we conducted paleo- and rock-magnetic analyses of samples from the Chiba composite section (CbCS), a continuous and expanded marine succession in Central Japan, to reconstruct the full sequence of the $\mathrm{M}-\mathrm{B}$ geomagnetic reversal. We define an average stratigraphic position of the $\mathrm{M}-\mathrm{B}$ boundary and estimate its age based on three sections in the CbCS and a neighboring drill core, TB-2. The average stratigraphic position of the M-B boundary in the CbCS is established at $1.1 \pm 0.3 \mathrm{~m}$ above a widespread volcanic ash bed (the Byk-E tephra). Assuming a chronological error associated with orbital tuning of $5 \mathrm{kyr}$ and stratigraphic uncertainty of $0.4 \mathrm{kyr}$, the M-B boundary in CbCS is at $772.9 \pm 5.4 \mathrm{ka}(1 \sigma)$. The virtual geomagnetic pole, which is calculated from the paleomagnetic directions, shows several short fluctuations between 783 and 763 ka, with concomitant decreases in geomagnetic field intensity index. After termination of the field instabilities, the field intensity recovered and became higher than before the M-B boundary, with a stable normal polarity direction. The paleomagnetic records in the CbCS exhibit a field asymmetry between the axial dipole decay and field recovery, providing a full sequence of the $M-B$ reversal, suggesting that the non-axial dipole field dominated several times during periods ca. $20 \mathrm{kyr}$ long across the M-B boundary, due to depletion in the main axial dipole component. Our results provide probably the most detailed sedimentary record of the $M-B$ geomagnetic reversal and offer valuable information to further understand the mechanism and dynamics of geomagnetic reversals.
\end{abstract}

Keywords: Paleomagnetism, Rock-magnetism, Matuyama-Brunhes geomagnetic reversal, Matuyama-Brunhes boundary, Relative paleointensity, Chiba composite section, Chiba section, GSSP, Chibanian Stage/Age, LowerMiddle Pleistocene boundary

\section{Introduction}

The Matuyama-Brunhes (M-B) geomagnetic reversal is the last polarity reversal and one of the most studied paleomagnetic events (e.g., Opdyke et al. 1966; Harrison 1974). The mid-point of the polarity switch interval (the

\footnotetext{
*Correspondence: yuuki.haneda.paleo@gmail.com

'National Institute of Polar Research, 10-3 Midori-cho, Tachikawa, Tokyo

190-8518, Japan

${ }^{2}$ Department of Earth Sciences, Ibaraki University, 2-2-1 Bunkyo, Mito, Ibaraki

310-8512, Japan

Full list of author information is available at the end of the article
}

directional transition from a reversed polarity to normal polarity) in the reversal ( $\mathrm{M}-\mathrm{B}$ boundary) is a critical stratigraphic marker for calibrating the age of sedimentary and volcanic sequences (e.g., Channell et al. 2010; Suganuma et al. 2015; Singer et al. 2019) and for defining the Lower-Middle Pleistocene boundary (Head et al. 2008; Head and Gibbard 2015; Suganuma et al. 2018). The timing of the M-B boundary has been consistently constrained to ca. $773 \mathrm{ka}$ in recent studies based on the astronomical age of rapidly accumulated marine 
sediments (e.g., Channell et al. 2010; Valet et al. 2014, 2019; Suganuma et al. 2018) and radiometric dating of volcanic ash and lava-flows (e.g., Suganuma et al. 2015; Singer et al. 2019).

Geomagnetic field structure during the $\mathrm{M}-\mathrm{B}$ geomagnetic reversal has also been intensively studied (e.g., Hartl and Tauxe 1996; Brown et al. 2004; Singer et al. 2005, 2019; Raisbeck et al. 2006; Sagnotti et al. 2014, 2016; Balbas et al. 2018; Macri et al. 2018). Paleomagnetic records from several marine sediments and lavas, and numerical model simulations, show that the polarity switch spans several thousand years depending on site location (e.g., Channell and Guydo 2004; Channell et al. 2010; Clement 2004; Singer et al. 2005; Amit et al. 2010; Olson et al. 2011; Valet et al. 2016). On the other hand, a remarkably short transition has been identified in exposed lacustrine sediments in the Sulmona Basin of the Central Apennines, Italy (Sagnotti et al. 2014, 2016) and marine sediments of the Valle di Manche section from Calabria, Southern Italy (Macri et al. 2018). In these studies, the polarity switch at the M-B boundary, dated at ca. $786 \mathrm{ka}$, was inferred to have completed within a century (Sagnotti et al. 2014; Macri et al. 2018). Prior to the M-B boundary, a clear decay in geomagnetic field intensity has been identified as a "precursor" event in deep-sea sediments (e.g., Hartl and Tauxe 1996; Channell et al. 2009), lavas (e.g., Brown et al. 2004; Singer et al. 2005), and ice (Raisbeck et al. 2006; Dreyfus et al. 2008). This precursor field decay is generally dated to ca. $795 \mathrm{ka}$ and appears to be of the same magnitude as that at the M-B boundary (e.g., Hartl and Tauxe 1996; Gotton et al. 2007). Recent paleomagnetic records from highly precisely ${ }^{40} \mathrm{Ar} /{ }^{39} \mathrm{Ar}$ dated lavas have indicated the long-term processes of the M-B geomagnetic reversal (Balbas et al. 2018; Singer et al. 2019). Based on these data, the field decay is thought to have begun ca. 30 kyrs before the polarity switch at ca. $773 \mathrm{ka}$, and involved centennial-tomillennial-scale field instabilities and a depletion of the axial dipole field (Balbas et al. 2018; Simon et al. 2018a; Singer et al. 2019). However, volcanic sequences fail to capture the entire $\mathrm{M}-\mathrm{B}$ geomagnetic reversal record due to the nature of sporadic volcanic eruptions, instead, recording near-instantaneous geomagnetic signals. Sedimentary sequences provide continuous records, but geomagnetic recordings in slowly accumulated sediments are affected by vertical and temporal offsets between the sediment/water interface and the lock-in depth of at least $10-15 \mathrm{~cm}$, the zone where the paleomagnetic record is fixed (e.g., Channell and Guydo 2004; Liu et al. 2008; Suganuma et al. 2010; Ménabréaz et al. 2012; Simon et al. 2018b). This may generate a smoothing effect due to progressively changing sedimentation-fabric processes (e.g., Suganuma et al.
2011; Roberts et al. 2013; Valet and Fournier 2016). Moreover, the sediment-recording smoothing process is amplified during paleomagnetic measurements due to the averaging effect of the magnetometer response window, when U-channels are used for the measurements (e.g., Oda and Xuan 2014; Philippe et al. 2018). These complex behaviors and the lack of truly continuousinstantaneous recordings have resulted in an incomplete picture of centennial-to-millennial-scale field behavior during the $\mathrm{M}-\mathrm{B}$ geomagnetic reversal.

A detailed paleomagnetic record of the $\mathrm{M}-\mathrm{B}$ geomagnetic reversal with a centennial-scale resolution was reported from the $130 \mathrm{~m}$ thick Chiba composite section in Central Japan (Fig. 1; Suganuma et al. 2015; Okada et al. 2017; Simon et al. 2019). On January 2020, the Chiba section, the main portion of the Chiba composite section, was ratified by the Executive Committee of the International Union of Geological Sciences as a Global Boundary Stratotype Section and Point (GSSP) for the Middle Pleistocene Subseries (Chibanian Stage/Age) (Fig. 1c). The M-B boundary, the primary marker of the GSSP, lies $1.1 \mathrm{~m}$ above the Byk-E tephra bed and is dated to $772.9 \mathrm{ka}$ (Suganuma et al. 2015, 2018; Okada et al. 2017; Simon et al. 2019). However, a complete sequence across the $\mathrm{M}-\mathrm{B}$ geomagnetic reversal was not then available because of a lack of data for the upper 36 $m$ portion of the Chiba composite section.

We report new paleomagnetic and rock-magnetic measurements for the upper part of the Chiba composite section. We also combine the results with those of Suganuma et al. (2015), Okada et al. (2017), and Simon et al. (2019), to reconstruct a full sequence of the M-B geomagnetic reversal in the interval between 794 and 748 $\mathrm{ka}$, which covers the entire interval of depletion of the geomagnetic field intensity, including the polarity switch and preceding transitional phase. Additionally, new samples identify the M-B boundary from a sub-section of the Chiba composite section, to confirm correlations between its sub-sections. For the first time using chronological and stratigraphic uncertainties between the Chiba composite section (Suganuma et al. 2015; Okada et al. 2017; our results) and a neighboring sediment core (Hyodo et al. 2016), we constrain the average age and stratigraphic position of the M-B boundary at the GSSP for the Chibanian Stage/Age and Middle Pleistocene Subseries/Subepoch.

\subsection{Geological and stratigraphic settings}

The Kazusa Group is the Pleistocene age marine succession exposed in the Boso Peninsula, Central Japan (Fig. $1 \mathrm{a}, \mathrm{b})$, which has been investigated in a number of studies (e.g., Kanehara et al. 1949; Kawai 1951; Shinada et al. 1951; Mitsunashi 1954; Mitsunashi et al. 1959; Nakajima 1978). The group is characterized by excellent and 


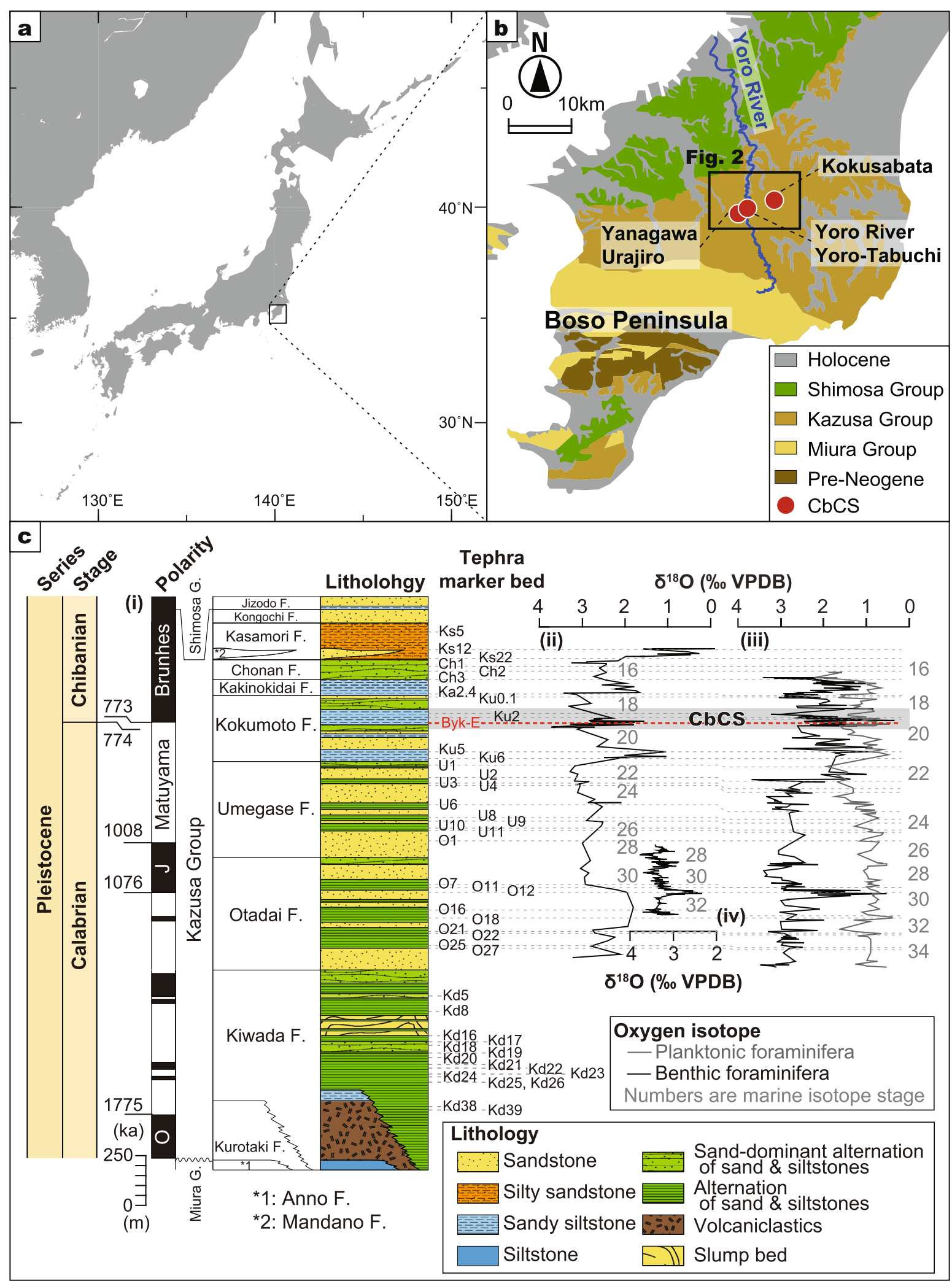

Fig. 1 (See legend on next page.) 
(See figure on previous page.)

Fig. 1 Location map of the study sites and stratigraphy of the Kazusa Group. a Map of the Japanese archipelago. b Distribution of marine successions on the Boso Peninsula and the location of the Chiba composite section. The black square indicates the area of the geological map in Fig. 2. c Stratigraphy of the Kazusa Group after Kazaoka et al. (2015): (i) Niitsuma (1976), (ii) Okada and Niitsuma (1989), (iii) Pickering et al. (1999), and (iv) Tsuji et al. (2005)

continuous exposure and exceptionally high sedimentation rates (ca. $2 \mathrm{~m} / \mathrm{kyr}$ ) (Kazaoka et al. 2015). The presence of many volcanic ash beds in the Boso Peninsula enables the reconstruction of a detailed stratigraphy (reviewed by Satoguchi and Nagahashi 2012; Fig. 1c). In addition, well-preserved marine microfossils (calcareous nannofossils, benthic and planktonic foraminifera, radiolaria, and diatoms) from the Kazusa Group have also been used to reconstruct biostratigraphies and a foraminiferal oxygen isotope stratigraphy (Aoki 1968; Oda 1977; Sato et al. 1988; Okada and Niitsuma 1989; Pickering et al. 1999; Cherepanova et al. 2002; Suganuma et al. 2018; Fig. 1c). These features provide a continuous, high-resolution chronostratigraphic framework.

The Chiba composite section in the middle part of the Kokumoto Formation, Kazusa Group, comprises the Yanagawa, Urajiro, Yoro River (including the Chiba section, the GSSP of the Chibanian Stage/Age), YoroTabuchi, and Kokusabata sub-sections (Figs. 2 and 3; Suganuma et al. 2018). A summary of the stratigraphic levels and locality of the Chiba composite section is shown in Table 1. The lithofacies of the middle part of the Chiba composite section is dominated by bioturbated silty beds with minor sandy beds, showing no evidence of episodic deposition and hiatus (Nishida et al. 2016), although thicker sandy beds are observable in the lowermost and upper parts (Fig. 3). Numerous tephra beds (Ku1, Ku2A, Ku2B, Tas, Tap, and Byk) occur in the Chiba composite section and demonstrate good correlation between sub-sections (Fig. 3; Suganuma et al. 2018). The Byk-E tephra bed, originating from the Older Ontake volcano in Central Japan (Takeshita et al. 2016), was ratified as the base of the Chibanian Stage/Age.

\subsection{Chronology of the Chiba composite section}

The chronological framework for dating the Chiba composite section is provided by correlation between the benthic oxygen isotope stratigraphy (Suganuma et al. 2018) and a sea-level proxy curve obtained from Ocean Drilling Project (ODP) Site 1123, offshore New Zealand (Elderfield et al. 2012), assisted by a U-Pb radiometric age of the Byk-E tephra (Suganuma et al. 2015). The resulting age model reveals that the Chiba composite section corresponds to an age range from the late part of marine isotope stage (MIS) $20(801.1 \mathrm{ka})$ to the early part of MIS 18 (747.6 ka) with the sedimentation rate varying between 0.44 and $3.87 \mathrm{~m} / \mathrm{kyr}$ (Suganuma et al. 2018; Haneda et al. 2020). In the Chiba section, the M-
B boundary is $1.1 \mathrm{~m}$ above the Byk-E tephra bed in an interval with a sedimentation rate of $89 \mathrm{~cm} / \mathrm{kyr}$ (Okada et al. 2017; Suganuma et al. 2018). The Byk-E tephra has a Th/U-corrected U-Pb zircon age of $772.7 \pm 7.2 \mathrm{ka}$ (Suganuma et al. 2015) and an astronomical age of $774.1 \mathrm{ka}$, which forms the basal age of the Chibanian Stage (Suganuma et al. 2018).

\subsection{Previous paleomagnetic studies in the Kokumoto Formation}

The $\mathrm{M}-\mathrm{B}$ boundary was identified in the middle part of the Kokumoto Formation of the Kazusa Group in the central Boso Peninsula by Nakagawa et al. (1969) and Niitsuma (1971, 1976) (Fig. 1c). These pioneering studies identified the M-B boundary approximately $2 \mathrm{~m}$ below the Byk-E tephra bed using alternating field (AF) demagnetization, which removes secondary remanences by exposing a specimen to an alternating magnetic field (Niitsuma 1971; Okada and Niitsuma 1989; Tsunakawa et al. 1995, 1999; Aida 1997).

Three paleomagnetic studies for the Chiba composite section have provided detailed records of geomagnetic field behavior across the M-B boundary (Suganuma et al. 2015; Okada et al. 2017; Simon et al. 2019). Suganuma et al. (2015) performed thermal demagnetization, which removes secondary remanence by heating and cooling specimens in a zero magnetic field. This was using specimens from the Chiba and Yanagawa sections between 6.55 and $5.75 \mathrm{~m}$ (indicated by blue horizontal bars in Fig. 3; Additional file 1: Table S1). The results of the thermal demagnetization indicate the $\mathrm{M}-\mathrm{B}$ boundary at $0.8 \mathrm{~m}$ above the Byk-E tephra bed at the Yanagawa section-not below the tephra bed as reported in earlier studies (Fig. 3). This difference to previous studies was interpreted as due to secondary remanence in the specimens, resulting from high coercivity magnetic minerals, that were not removed by AF demagnetization in the early studies. However, relative paleointensity could not be reconstructed, because minerals in the specimens underwent heat-alteration during the thermal demagnetization process, producing new magnetic phases (Suganuma et al. 2015).

Okada et al. (2017) conducted demagnetization using a hybrid method of thermal demagnetization at $300^{\circ} \mathrm{C}$ followed by progressive AF demagnetization for specimens from the Chiba and Yoro-Tabuchi sections between -14.6 and $9.7 \mathrm{~m}$ (indicated by black horizontal bars in Fig. 3; Additional file 2: Table S2). This hybrid demagnetization method removes the secondary 

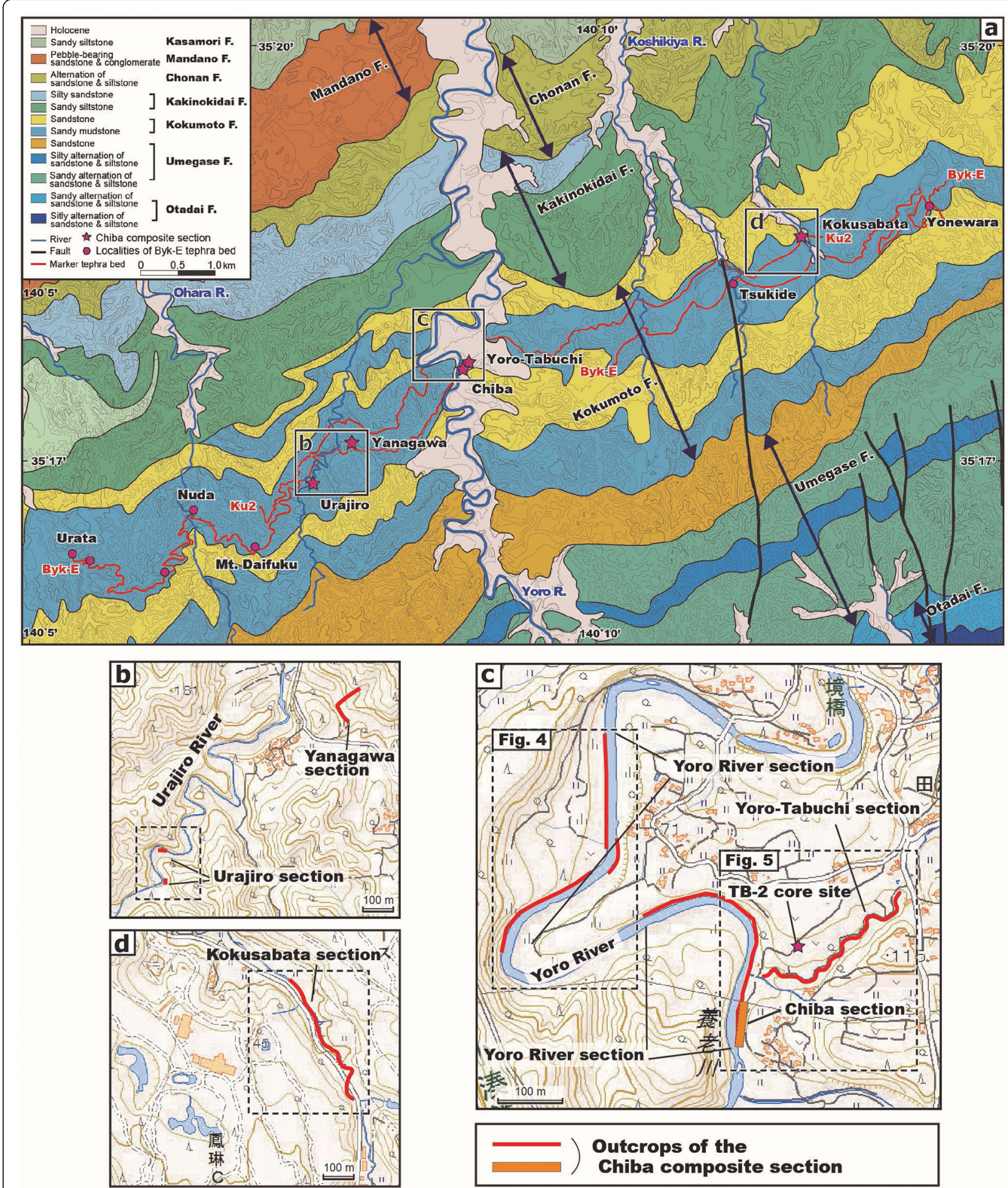

Fig. 2 Location of the Chiba composite section (CbCS). a Geological map of the central Boso Peninsula after Suganuma et al. (2018). Red stars indicate locations of the sub-sections of the CbCS. $\mathbf{b}$ - $\mathbf{d}$ Detailed maps of the sub-sections of the CbCS, as indicated by the black squares in $\mathbf{a}$

remanence, which cannot be removed by $\mathrm{AF}$ demagnetization alone, importantly with minimum heat-alteration, therefore allowing reconstruction of relative paleointensity (such a procedure is widely used for similar reasons in many other sedimentbased studies). Based on this hybrid approach, the 


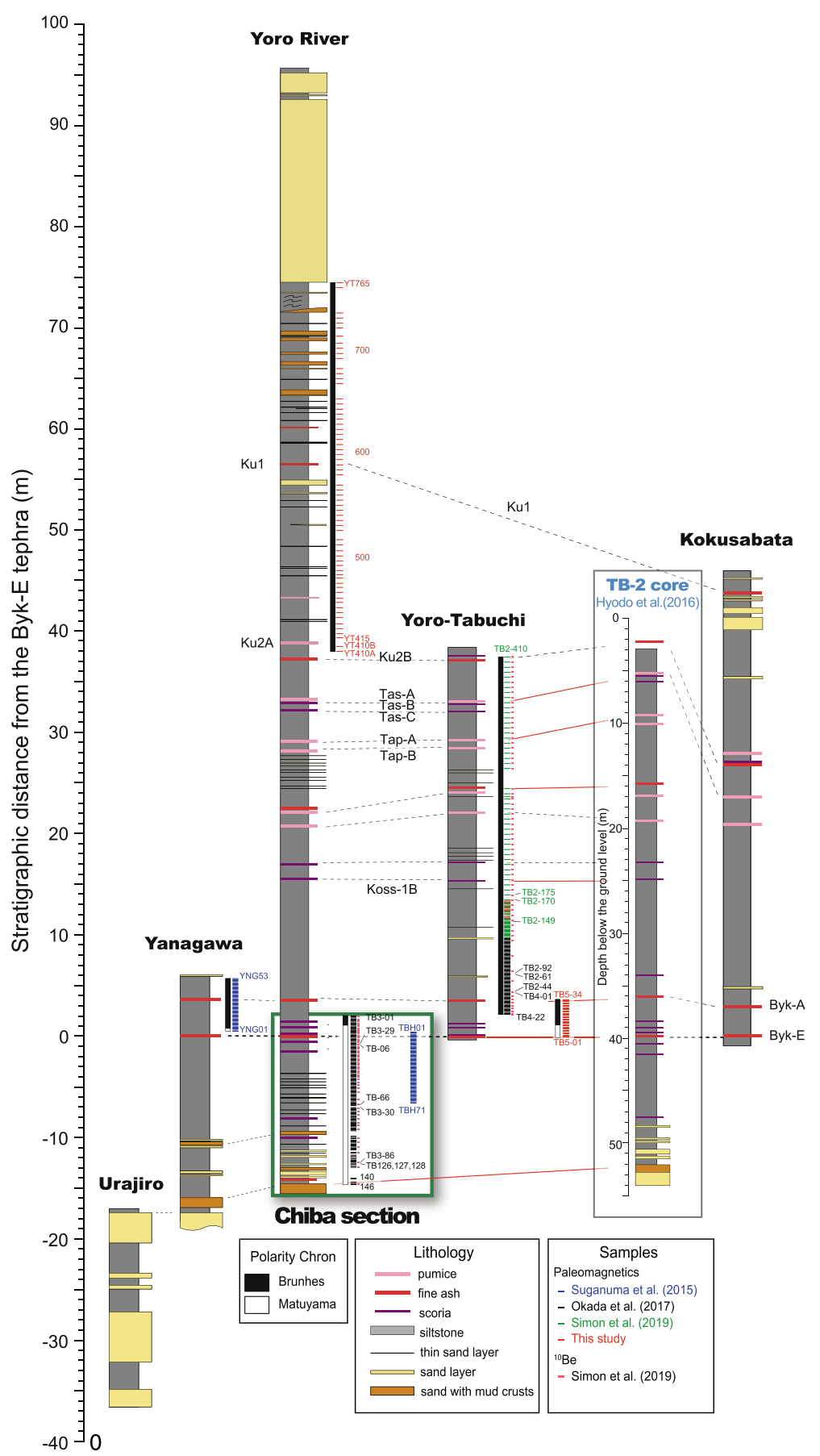

Fig. 3 Lithological columns of the sub-sections of the Chiba composite section (and TB-2 core) after Suganuma et al. (2018) and Hyodo et al. $(2016$, 2017). Blue, black, green, and red horizontal bars indicate sampling levels in Suganuma et al. (2015), Okada et al. (2017), Simon et al. (2019), and this study, respectively. Green squares indicate sampling levels for ${ }^{10} \mathrm{Be}$ measurements of Simon et al. (2019). The stratigraphic correlation between the Chiba composite section and the TB-2 core is indicated by red solid lines. TBxx, TB2-xx, TB3-xx, TB4-xx, TBHxx, and YNGxx are sample codes. Byk-A, Byk-E, Ku1, Ku2A, Ku2B, Koss-1B, Tap-A, Tap-B, Tas-A, Tas-B, and Tas-C are local tephra marker beds

M-B boundary was observed, with a depleted geomagnetic field intensity at $1.1 \mathrm{~m}$ above the Byk-E tephra bed in the Chiba section (Fig. 3). The redefined stratigraphic position of the $\mathrm{M}-\mathrm{B}$ boundary is supported by paleomagnetic data from the TB-2 sediment core drilled $190 \mathrm{~m}$ northeast of the Chiba section (Hyodo et al. 2016; Figs. 3 and 4). However, the recovery phase of the geomagnetic field (after the 
Table 1 Summary of the stratigraphic interval based on the oxygen isotope sampling levels and locality of the Chiba composite section

\begin{tabular}{|c|c|c|c|c|}
\hline \multirow[t]{2}{*}{ Section } & \multicolumn{2}{|c|}{ Level $(m)^{a}$} & \multicolumn{2}{|c|}{ Latitude / Longitude } \\
\hline & Top & Bottom & Top & Bottom \\
\hline Chiba $^{b}$ & 2.20 & -15.50 & $\begin{array}{l}35^{\circ} 17^{\prime} 39.6^{\prime \prime} \mathrm{N} / \\
140^{\circ} 08^{\prime} 47.6^{\prime \prime} \mathrm{E}\end{array}$ & $\begin{array}{l}35^{\circ} 17^{\prime} 36.9^{\prime \prime} \mathrm{N} / \\
140^{\circ} 08^{\prime} 47.2^{\prime \prime} \mathrm{E}\end{array}$ \\
\hline Yoro River ${ }^{c}$ & 95.50 & -15.50 & $\begin{array}{l}35^{\circ} 17^{\prime} 59.6^{\prime \prime} \mathrm{N} / \\
140^{\circ} 08^{\prime} 34.8^{\prime \prime} \mathrm{E}\end{array}$ & $\begin{array}{l}35^{\circ} 17^{\prime} 36.9^{\prime \prime} \mathrm{N} / \\
140^{\circ} 08^{\prime} 47.2^{\prime \prime} \mathrm{E}\end{array}$ \\
\hline $\begin{array}{l}\text { Yoro- } \\
\text { Tabuchi }\end{array}$ & 37.50 & 0.05 & $\begin{array}{l}35^{\circ} 17^{\prime} 48.1^{1 " N} / \\
140^{\circ} 09^{\prime} 02.1^{\prime \prime} \mathrm{E}\end{array}$ & $\begin{array}{l}35^{\circ} 17^{\prime} 41.1 \mathrm{ln}^{\mathrm{N}} / \\
140^{\circ} 08^{\prime} 49.7^{\prime \prime} \mathrm{E}\end{array}$ \\
\hline Kokusabata $^{\mathrm{d}}$ & 57.07 & 7.87 & $\begin{array}{l}35^{\circ} 18^{\prime} 43.2^{\prime \prime N} / \\
140^{\circ} 11^{\prime} 45.7^{\prime \prime} \mathrm{E}\end{array}$ & $\begin{array}{l}35^{\circ} 18^{\prime} 32.7^{\prime \prime N} / \\
140^{\circ} 11^{\prime} 53.6^{\prime \prime E}\end{array}$ \\
\hline Yanagawa $^{d}$ & 5.60 & -15.93 & $\begin{array}{l}35^{\circ} 17^{\prime} 08.9^{\prime \prime} \mathrm{N} / \\
140^{\circ} 07^{\prime} 52.9^{\prime \prime} \mathrm{E}\end{array}$ & $\begin{array}{l}35^{\circ} 17^{\prime} 05.8^{\prime \prime} \mathrm{N} / \\
140^{\circ} 07^{\prime} 51.0^{\prime \prime} \mathrm{E}\end{array}$ \\
\hline Urajiro $^{d}$ & -19.67 & -34.21 & $\begin{array}{l}35^{\circ} 16^{\prime} 52.4^{\prime \prime} \mathrm{N} / \\
140^{\circ} 07^{\prime} 28.2^{\prime \prime} \mathrm{E}\end{array}$ & $\begin{array}{l}35^{\circ} 16^{\prime} 49.4^{\prime \prime} \mathrm{N} / \\
140^{\circ} 07^{\prime} 28.3^{\prime \prime} \mathrm{E}\end{array}$ \\
\hline
\end{tabular}

${ }^{\mathrm{a} S t r a t i g r a p h i c ~ l e v e l s ~ a r e ~ i n d i c a t e d ~ a s ~ s t r a t i g r a p h i c ~ d i s t a n c e ~ f r o m ~ t h e ~ B y k-E ~}$ tephra bed

${ }^{b}$ The stratigraphic interval of the Chiba section is based on the full range of the outcrop

'The Yoro River section contains the Chiba section

${ }^{\mathrm{d}}$ The stratigraphic levels are converted into the scale of the Yoro River and Yoro-Tabuchi sections

polarity switch) was not observed by Okada et al. (2017) due to a lack of samples collected from the Byk-E tephra bed above the $9.7 \mathrm{~m}$ level.

Simon et al. (2019) undertook paleomagnetic measurements of samples from the Yoro-Tabuchi section between 9.8 and $37.5 \mathrm{~m}$ (indicated by green horizontal bars in Fig. 3; Additional file 2: Table S2) and beryllium isotope measurements of samples from the Chiba and Yoro-Tabuchi sections up to $37.5 \mathrm{~m}$ (indicated by pink squares in Fig. 3). Based on their measurements, the paleomagnetic direction and relative paleointensity records were obtained, along with a beryllium isotope record $\left({ }^{10} \mathrm{Be},{ }^{9} \mathrm{Be}\right.$, and ${ }^{10} \mathrm{Be} /{ }^{9} \mathrm{Be}$ ratio), as independent proxies of the geomagnetic field intensity. These authors suggested that the M-B boundary involved geomagnetic dipole moment collapse and observed a sequence of rapid directional oscillations between the $\mathrm{M}-\mathrm{B}$ boundary and the later field recovery phase, in which a stable dipole is reestablished on the opposite direction. The directional oscillations were identified as instability clusters $(\mathrm{IC} 1=771.9-768.5 \mathrm{ka}, \mathrm{IC} 2=768.5-$ $765.2 \mathrm{ka}$, and IC3 $=763.5-762.5 \mathrm{ka}$ ) by Simon et al. (2019).

These previous paleomagnetic studies of the Chiba composite section have reconstructed a centennialresolution paleomagnetic record from the stratigraphic interval between - 14.6 and $37.5 \mathrm{~m}$ from the Byk-E tephra bed. Exceptionally high sedimentation rates of the Chiba composite section are thought to limit the lock-in depth and smoothing effect of the geomagnetic field recording process (e.g., Suganuma et al. 2011; Valet and Fournier 2016). Therefore, the sedimentary succession documents short-duration instabilities of the geomagnetic field that are almost simultaneous with deposition. However, paleoand rock-magnetic records from the strata above $37.5 \mathrm{~m}$ have not yet been obtained. In addition, although the M$B$ boundary is located $1.1 \mathrm{~m}$ above the Byk-E tephra bed in the Chiba section, this boundary has not been examined in the Yoro-Tabuchi section, $70 \mathrm{~m}$ northeast of the Chiba section (Figs. 2c and 4).

\section{Methods}

\subsection{Paleomagnetic core samples}

We collected $25 \mathrm{~mm}$-diameter drill core samples from the upper part of the Yoro River section and the lowermost and middle parts of the Yoro-Tabuchi section using a portable drill (Figs. 3, 4, and 5). For the Yoro River section (above $37.5 \mathrm{~m}$ ), the drill cores were collected from 64 levels with a ca. $50 \mathrm{~cm}$ spacing (the same interval as used for deriving the foraminiferal oxygen isotope stratigraphy of Suganuma et al. 2018 and Haneda et al. 2020). The locations of the collected samples are indicated by red horizontal bars in Fig. 3 and red letters in Fig. 5. In the lowermost $(0 \mathrm{~m}$ to $3.8 \mathrm{~m})$ and middle $(11.6 \mathrm{~m}$ to $13.4 \mathrm{~m})$ part of the Yoro-Tabuchi section, drill cores were collected from 34 levels and 9 levels with a ca. 10 to $20 \mathrm{~cm}$ spacing, as indicated by red horizontal bars in Fig. 3 and red letters in Fig. 4. These samples were oriented with a magnetic compass. Each core was cut into $2 \mathrm{~cm}$-long specimens for subsequent paleomagnetic and rockmagnetic measurements at Ibaraki University and $\mathrm{Na}$ tional Institute of Polar Research (NIPR).

\subsection{Paleomagnetic measurements}

The natural remanent magnetization (NRM) for each specimen was measured using a three-axis cryogenic magnetometer SRM-760R (2G Enterprises, USA) in a magnetically shielded room at the NIPR. To extract the primary magnetic component, we removed the secondary remanence from the NRMs using a hybrid of thermal demagnetization to $300^{\circ} \mathrm{C}$ and AF demagnetization (Okada et al. 2017). The thermal demagnetization was conducted using a TDS1 (Natsuhara Giken, Japan) at the NIPR. The progressive AF demagnetization was performed in 5 to 10 $\mathrm{mT}$ increments between 5 and $20 \mathrm{mT}$ before the thermal demagnetization and between 20 and $80 \mathrm{mT}$ after the thermal demagnetization, using static threeaxis AF demagnetization coils in an SRM-760R magnetometer at the NIPR.

We identified the characteristic remanent magnetization (ChRM) at peak AF fields between 30 to $50 \mathrm{mT}$ after the thermal demagnetization at $300^{\circ} \mathrm{C}$ (Okada et al. 2017; Simon et al. 2019) and calculated paleomagnetic directions by principal component analysis (Kirschvink 1980) using these step points with anchoring to the origin. The virtual geomagnetic pole (VGP) was calculated using the ChRM directions with 


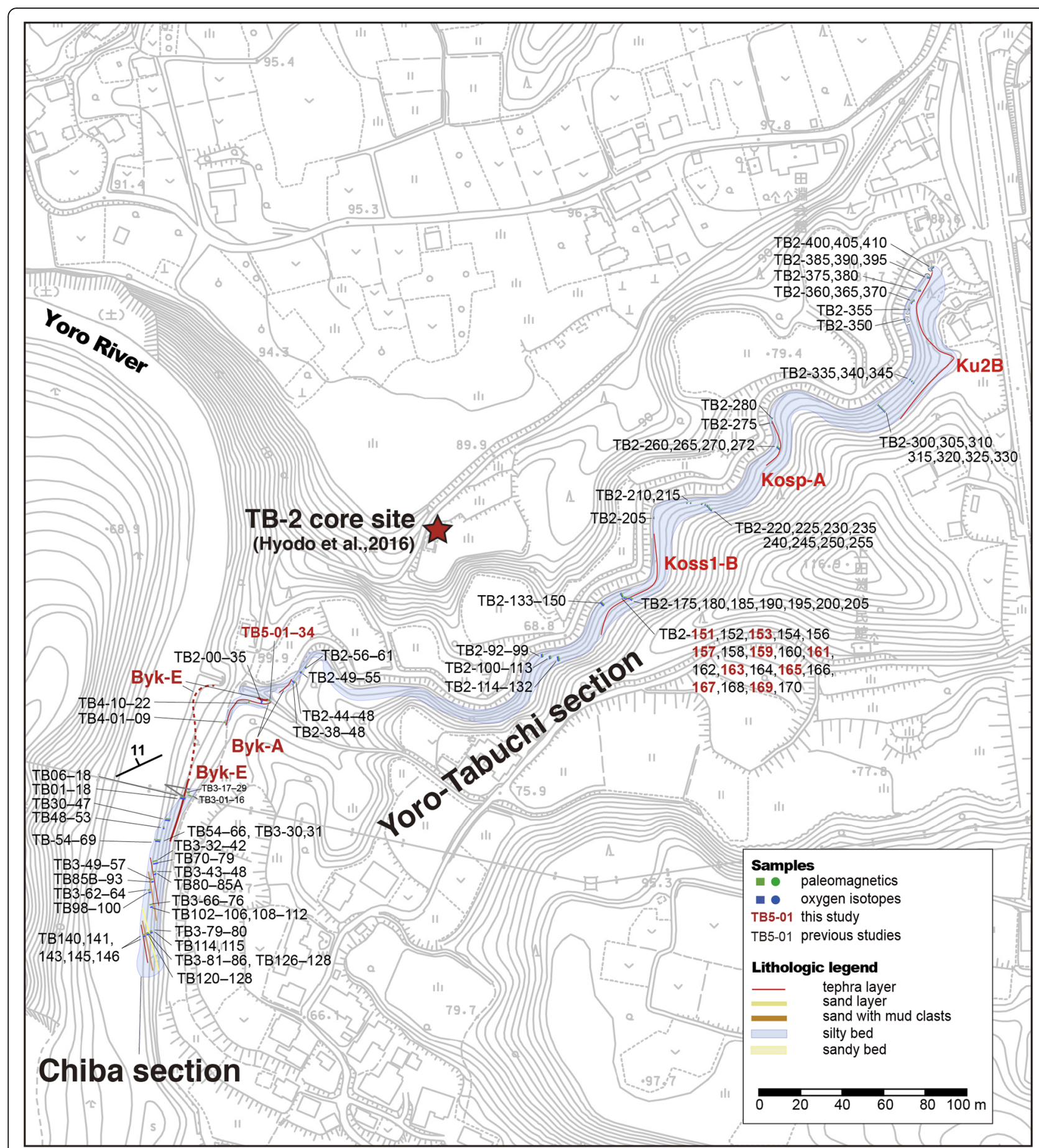

Fig. 4 Sampling location in the lower part of the Yoro River section (Chiba section) and the Yoro-Tabuchi section. Circles and squares indicate sampling sites for paleomagnetic (green) and oxygen isotope (blue) analyses. Sample codes for samples collected by previous studies (Okada et al. 2017; Suganuma et al. 2018; Simon et al. 2019; Haneda et al. 2020) and this study are shown by black and red letters and numbers, respectively. The drilling site for the TB-2 sediment core is indicated by a red star (Hyodo et al. 2016)

maximum angular deviation (MAD) of $\leq 15^{\circ}$. We identified magnetic polarities based on VGP latitudes, where VGP latitudes $>45^{\circ}$ were defined as normal polarity, latitudes $<-45^{\circ}$ were defined as reversed polarity, and latitudes of -45 to $+45^{\circ}$ were defined as intermediate polarity. In this study we define the M-B boundary as the mid-point of the polarity switch interval between the older reversed polarity (VGP latitudes $<-45^{\circ}$ ) to normal polarity (VGP latitudes $>45^{\circ}$ ). 


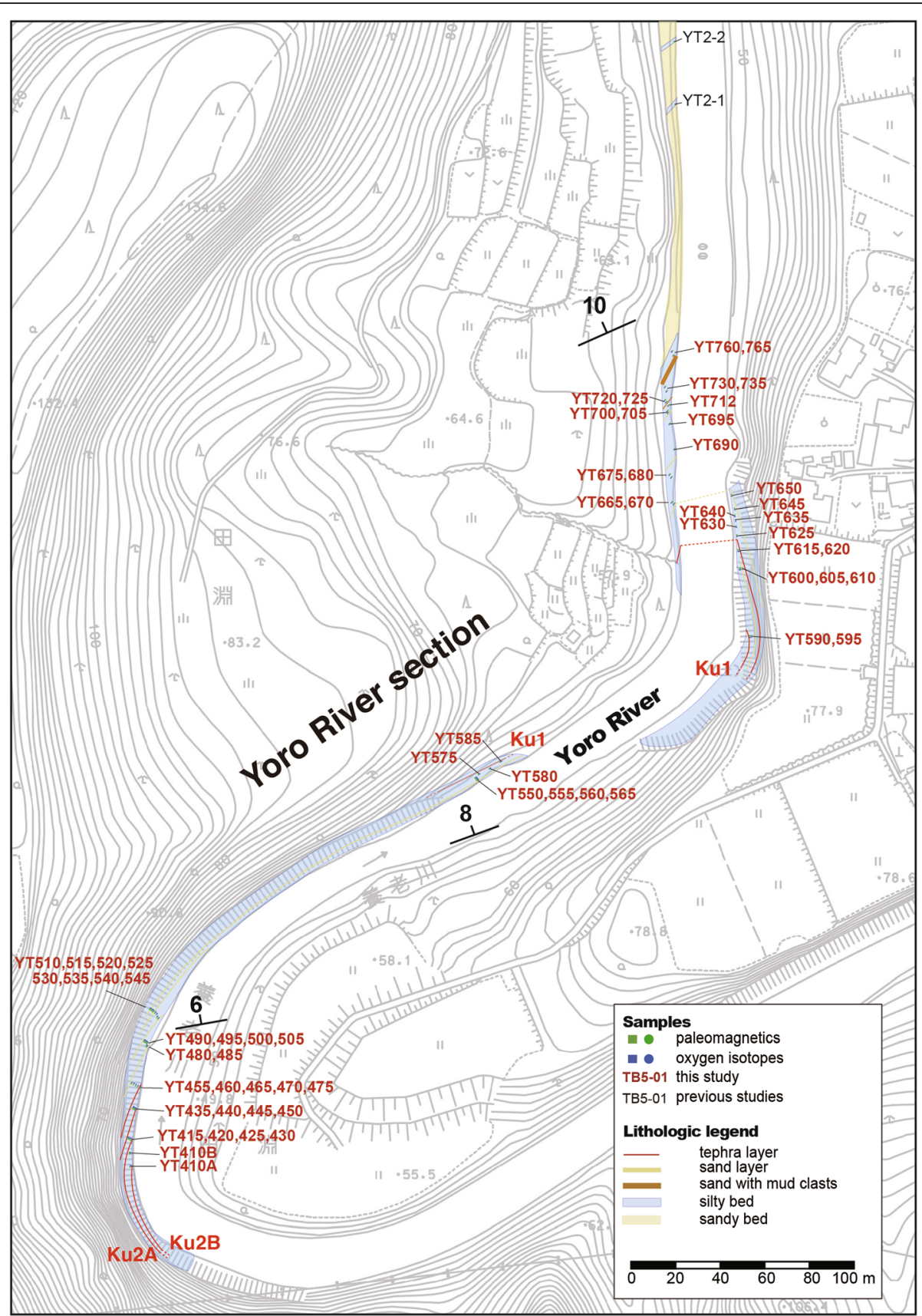

Fig. 5 Sampling location in the upper part of the Yoro River section. Green and blue circles indicate sampling sites for paleomagnetic and oxygen isotope analyses, respectively. Sample codes of samples collected by previous studies (Suganuma et al. 2018; Haneda et al. 2020) and this study are shown by black and red letters and numbers, respectively

\subsection{Rock-magnetic measurements}

To determine rock-magnetic properties and calculate the relative paleointensity indices, we measured low-field magnetic susceptibility $\left(k_{\mathrm{LF}}\right)$, laboratory-induced magnetizations of anhysteretic remanent magnetization (ARM), and isothermal remanent magnetization (IRM).

Measurements of the $k_{\mathrm{LF}}$ were performed on specimens using a KLY-3S Kappabridge susceptibility meter
(AGICO, Czech Republic) at Ibaraki University, before any paleomagnetic or rock-magnetic measurements were made. For specimens whose NRM was demagnetized by the hybrid method, ARM was acquired in a $30 \mu \mathrm{T}$ DC field with an $80 \mathrm{mT}$ alternating field using the SRM760R magnetometer at the NIPR. In each case, after ARM acquisition, we repeated the hybrid demagnetization (thermal demagnetization at $300{ }^{\circ} \mathrm{C}$ and 
AF demagnetization) at $10 \mathrm{mT}$ increments between 20 and $80 \mathrm{mT}$. ARM susceptibility $\left(k_{\mathrm{ARM}}\right)$ was calculated from the initial ARM intensity.

$k_{\text {ARM }}$ is mainly preferentially acquired by small magnetic grains with weak magnetostatic interaction. On the other hand, $k_{\mathrm{LF}}$ mainly reflects the total amount of magnetic minerals in a specimen, irrespective of the magnetic grain size. Therefore, the $k_{\mathrm{ARM}} / k_{\mathrm{LF}}$ ratio is a conventional proxy for the grain size of magnetic particles in a specimen; an increase in the $k_{\mathrm{ARM}} / k_{\mathrm{LF}}$ ratio indicates the relative contribution of finer magnetic particles and vice versa (e.g., Yamazaki 2008; Yamazaki and Ikehara 2012; Shin et al. 2019).

After the ARM experiments, we exposed selected specimens to saturated IRM (SIRM) in a $1.5 \mathrm{~T}$ field using a MMPM-9 pulse magnetizer (Magnetic Measurements Ltd., UK). The SIRM was measured using a JR-6A magnetometer (AGICO, Czech Republic) and demagnetized using a TD-48 thermal demagnetizer (ASC Scientific, USA) and AF demagnetizer DEM-8601C (Natsuhara-Giken, Japan) at Ibaraki University. Results from the hybrid demagnetization method used on the ARM, along with the SIRM, were used to calculate relative paleointensity indices as outlined below.

To determine S-ratios, IRM acquisition was performed on unprocessed specimens. S-ratios indicate the relative abundance of antiferromagnetic minerals (such magnetically hard hematite and goethite) in a mixture with ferrimagnetic minerals (such as magnetically soft magnetite and maghemite); values close to unity indicate that the remanence is dominated by magnetically soft ferrimagnets and vice versa (Bloemendal et al. 1992; Evans and Heller 2003). We imparted SIRM on selected specimens from the Yoro River and Yoro-Tabuchi sections above $9.7 \mathrm{~m}$ using a $1.5 \mathrm{~T}$ field using the MMPM-9 pulse magnetizer (Magnetic Measurements Ltd., UK). The IRM was then measured using the JR-6A magnetometer (AGICO, Czech Republic) at Ibaraki University. IRMs at $0.1 \mathrm{~T}$ and $0.3 \mathrm{~T}$ fields were acquired in the opposite direction of the SIRM. The S-ratio- $0.1 \mathrm{~T}$ and Sratio $_{-0.3 \mathrm{~T}}$ were calculated as

$\mathrm{S}-$ ratio $_{-0.3 \mathrm{~T}(-0.1 \mathrm{~T})}=\left(\left(-\mathrm{IRM}_{-0.3 \mathrm{~T}(-0.1 \mathrm{~T})} / \mathrm{SIRM}\right)+1\right) / 2$

according to Bloemendal et al. (1992).

\subsection{Relative paleointensity}

Proxies of magnetic grain concentration, $k_{\mathrm{LF}}$, ARM, or IRM, are usually employed to normalize NRM when calculating the relative paleointensity index (e.g., Kent and Opdyke 1977; Tauxe 1993; Tauxe and Shackleton 1994; Guyodo and Valet 1999; Yamazaki 1999; Valet 2003; Yamazaki and Kanamatsu 2007; Suganuma et al. 2008). Previous studies of the Chiba composite section calculated the relative paleointensity by normalizing the vector difference of the NRM between $30 \mathrm{mT}$ and 50 $\mathrm{mT}$ (after thermal demagnetization at $300^{\circ} \mathrm{C}$ ) with the ARM intensity removed between the same demagnetization steps after thermal demagnetization at $300{ }^{\circ} \mathrm{C}$ (Okada et al. 2017; Simon et al. 2019). However, the pseudo-Thellier approach of Tauxe et al. (1995) or other related method has been widely employed to deduce the paleointensity. In the approach of Tauxe et al. (1995), the slope of the NRM intensity left at a certain demagnetization step normalized against ARM or IRM intensity gain at the same imparted field step was used as the paleointensity proxy. In practice, the slope of the NRM intensity left at selected demagnetization steps against the ARM or IRM left at the same demagnetization steps has been more widely used (e.g., Channell et al. 2002; Valet et al. 2014). Moreover, normalization by ARM may over-compensate magnetic concentration changes because ARM can be sensitive to magnetostatic interaction among grains (Yamazaki and Kanamatsu 2007). As a result, the efficiency of ARM acquisition in specimens can decrease with an increase in magnetic concentration.

Therefore, we normalized the NRM against the ARM (or IRM) as $\mathrm{NRM}_{30-50} / \mathrm{ARM}_{30-50}$ (or $\mathrm{NRM}_{30-50} / \mathrm{IRM}_{30-}$ 50) from NRM lost versus ARM (or IRM) lost between the 30 and $50 \mathrm{mT}$ demagnetization steps (after thermal demagnetization at $300^{\circ} \mathrm{C}$ ). We employed these ratios as relative paleointensity indices. $k_{\mathrm{LF}}$ was not used as a normalizer in this study, because it may be less effective due to possible influence from diamagnetic and paramagnetic minerals and large ferrimagnetic grains that do not carry NRM (Shin et al. 2019). The Pearson linear correlation coefficient (R-value ${ }_{A R M}$ and R-value IRM $_{\text {), as- }}$ sociated with the slope of the NRM intensity left at certain demagnetization steps against the ARM or IRM left at the same demagnetization steps, was calculated to monitor the goodness of the slope fit (Channell et al. 2002; Shin et al. 2019). A comparison of the proxies used for relative paleointensity between this study and the previous studies (Okada et al. 2017; Simon et al. $2019)$ is in Figure S1.

\section{Results and discussion}

\subsection{Remanent magnetization}

Representative orthogonal vector diagrams (Zijderveld 1967) of the NRMs are shown in Fig. 6. Some of the data for intermediate and reversed polarities before and after the M-B boundary are taken from Okada et al. (2017) and Simon et al. (2019) (Fig. 6c, d, h, and i). The magnetization from the Chiba composite section consists of one or more components (Fig. 6). The component before thermal demagnetization at $300^{\circ} \mathrm{C}$ generally is the secondary component. After thermal demagnetization at $300^{\circ} \mathrm{C}$, several 


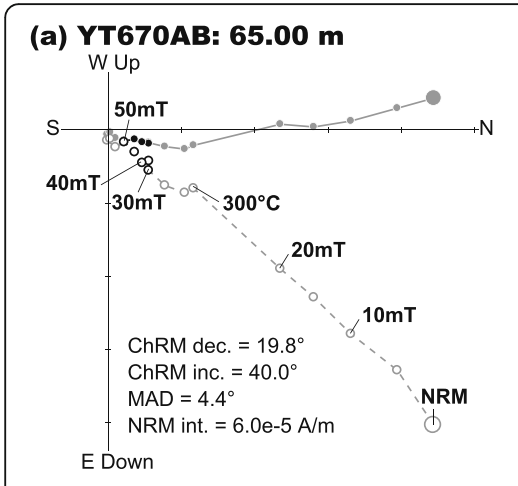

(d) TB2-100AA: $6.50 \mathrm{~m}$

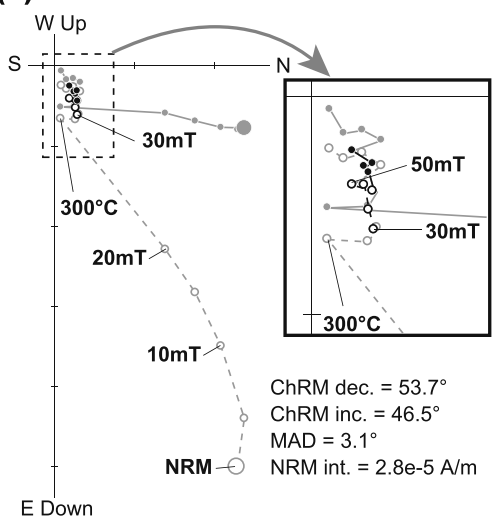

(g) TB5-02AA: $0.17 \mathrm{~m}$

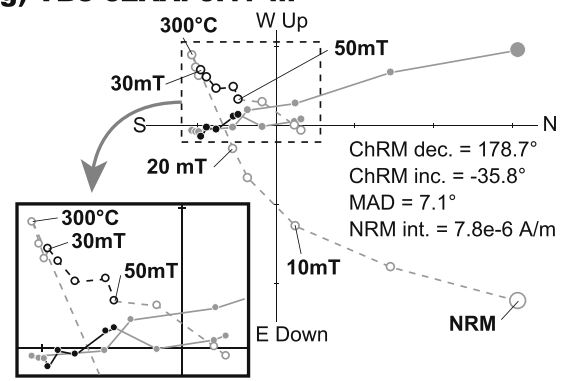

Horizontal component

$\bigcirc$ Vertical component (b) YT485AB: $46.05 \mathrm{~m}$

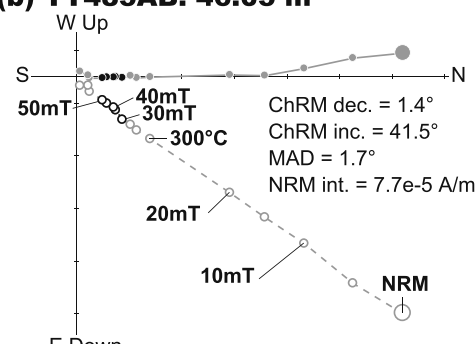

(e) TB5-31BA: $3.44 \mathrm{~m}$

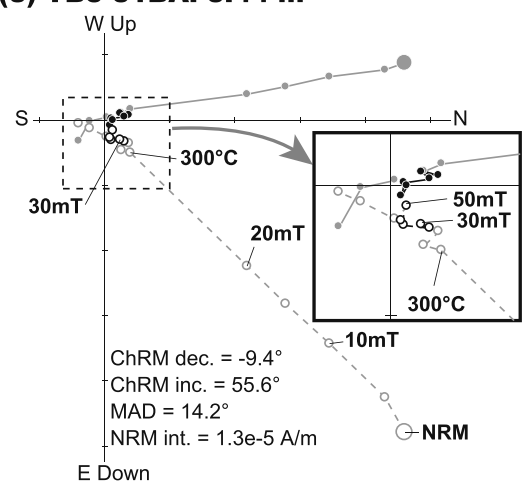

(h) TB50AB: $\mathbf{- 5 . 0 5} \mathrm{m}$

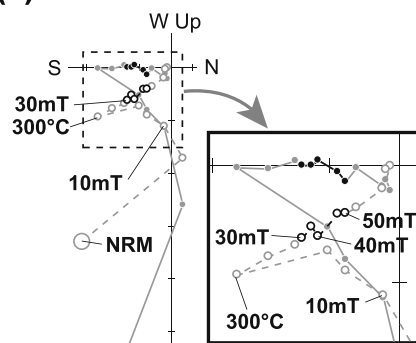

ChRM dec. $=177.0^{\circ}$ ChRM inc. $=39.1^{\circ}$ $\mathrm{MAD}=5.2^{\circ}$ NRM int. $=4.2 \mathrm{e}-5 \mathrm{~A} / \mathrm{m}$ (c) TB2-161AB: $12.60 \mathrm{~m}$

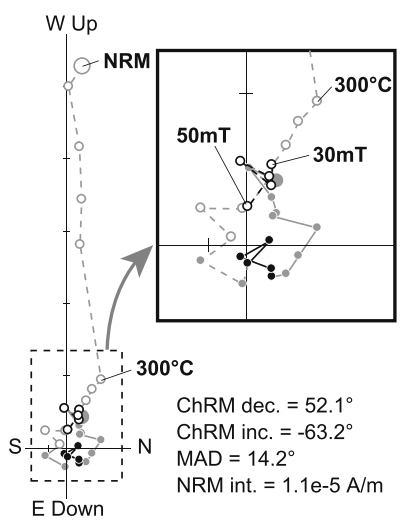

(f) TB5-11AA: $1.18 \mathrm{~m}$

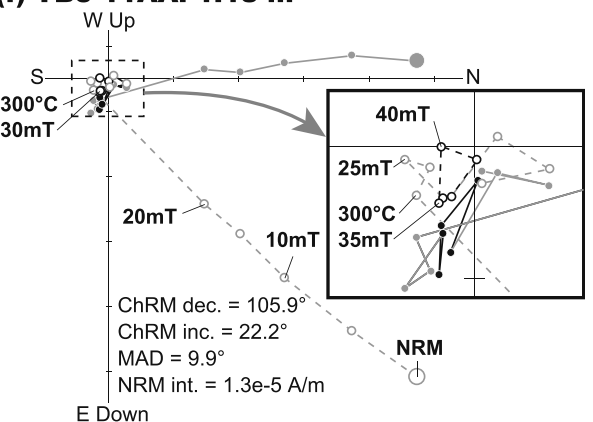

Fig. 6 Orthogonal vector diagrams for representative results of the hybrid demagnetization method. a, b Results indicating normal polarity from the upper part of the Yoro River section (this study). c, d Results indicating intermediate polarity in the interval of instability clusters (IC1-IC3) from the Yoro-Tabuchi section (c Simon et al. 2019; d Okada et al. 2017). e-g Specimen data across the M-B boundary in the lowermost part of the Yoro-Tabuchi section (this study). $\mathbf{h}$, i Results from the Matuyama reversed polarity interval from the Chiba section (Okada et al. 2017). Closed and open circles indicate horizontal and vertical components, respectively. Closed and open black data points were used to calculate characteristic remanent magnetization in the principal component analysis

specimens showed a ChRM between 30 and $50 \mathrm{mT}$, which decays toward the origin (Fig. $6 \mathrm{~b}-\mathrm{i}$ ).

Okada et al. (2017) revealed that some samples from the Chiba composite section became unstable to thermal demagnetization at temperatures above $300{ }^{\circ} \mathrm{C}$, and the following AF demagnetization between 30 and $50 \mathrm{mT}$ appeared to reflect-well the ChRM decay towards the origin. Because the samples have a single Curie/Néel temperature at $580{ }^{\circ} \mathrm{C}$ (Suganuma et al. 2015; Okada et al. 2017), the component between 30 and $50 \mathrm{mT}$ is thought to be carried by magnetite. Based on the result of Suganuma et al. (2015) and Okada et al. (2017), also 
the component between 30 and $50 \mathrm{mT}$, probably carried by magnetite, is identified as the primary remanence. Repeated thermomagnetic experiments performed in the air show no distinct heat-alteration of magnetic minerals until $400{ }^{\circ} \mathrm{C}$ (Okada et al. 2017). Therefore, we calculated paleomagnetic directions of the ChRM between the 30 and $50 \mathrm{mT}$ steps, following the thermal demagnetization at $300^{\circ} \mathrm{C}$.

\subsection{Rock-magnetic properties and paleomagnetic directions in the Yoro River section}

The rock magnetic properties in the upper part of the Yoro River section (indicated by red and orange circles in Fig. 7; Additional file 2: Table S2) are relatively homogenous as are those from lower in the Chiba composite section. Proxies of magnetic grain concentration $\left(k_{\mathrm{LF}}, k_{\mathrm{ARM}}\right)$ show simultaneous and minor fluctuations by a factor of $<10$ throughout the Chiba composite section (Fig. $7 \mathrm{k}$ ). The $k_{\mathrm{ARM}} / k_{\mathrm{LF}}$ ratio-a proxy of magnetic grain size-varies between 1.5 and 4.4 throughout the section (Fig. 7l). The S-ratio $-0.3 \mathrm{~T}$, which represents the relative abundance of antiferromagnetic minerals in a mixture with ferrimagnetic minerals, fluctuates moderately throughout the Chiba composite section except in the Yoro River section above $67 \mathrm{~m}$ (Fig. $7 \mathrm{~m}$ ). The average S-ratio $-0.3 \mathrm{~T}$ of 0.96 indicates that the magnetic grains throughout the Chiba composite section mostly consist of ferrimagnetic minerals (Frank and Nowaczyk 2008).

While the S-ratio $-0.1 \mathrm{~T}$ fluctuates between 0.66 and 0.90 in the Chiba and lower Yoro-Tabuchi sections (Okada et al. 2017), the fluctuation amplitude is suppressed in the upper parts of these sections (Fig. $7 \mathrm{~m}$ ). The periodic decrease of the S-ratio- $0.1 \mathrm{~T}$ in the Yoro-Tabuchi and Chiba sections is thought to be not attributed to the increase in the proportion of hematite or goethite, but mainly to the increase (decrease) in the amount of fine (coarse) size magnetic grain, because of its cooccurrence with changes in $k_{\mathrm{ARM}} / k_{\mathrm{LF}}$ (Yamazaki et al. 2003; Suganuma et al. 2008; Okada et al. 2017). This interpretation is supported by the high average value of the S-ratio $-0.3 \mathrm{~T}(0.96)$, indicating the dominance of ferrimagnetic minerals throughout the Chiba composite section (Frank and Nowaczyk 2008; Fig. 7m). Additionally, the amplitude of the $k_{\mathrm{ARM}} / k_{\mathrm{LF}}$ changes is limited to a factor of $<3$. These data indicate that the magnetic properties throughout the Chiba composite section are generally uniform, although minor grain size changes occur in the lower interval. Therefore, the rockmagnetic data of the Chiba composite section fulfill the established criteria for the construction of a robust relative paleointensity record with respect to magnetic grain concentration, magnetic grain size, and magnetic mineralogy (Tauxe 1993). However, the S-ratio $-0.3 \mathrm{~T}$ and Sratio $_{-0.1 \mathrm{~T}}$ in the Yoro River section above the $67 \mathrm{~m}$ level decrease to 0.86 and 0.46 , respectively (Fig. $7 \mathrm{~m}$ ). These decreases are accompanied by decreases in the relative paleointensity indices, linear correlation coefficients (Rvalue $_{\mathrm{ARM}}$ and R-value $\mathrm{IRM}_{\mathrm{IRM}}$ ), NRM intensity, and proxies of magnetic concentration (Fig. $7 \mathrm{e}-\mathrm{h}, \mathrm{j}-\mathrm{k}$, and $\mathrm{m}$ ). No distinct lithological change was observed in this stratigraphic interval in the field. As the interval above $67 \mathrm{~m}$ corresponds to just after the full glacial interval of MIS 18, in the oxygen isotope stratigraphy (Fig. 7b; Haneda et al. 2020), the change in the magnetic properties may have originated from local environmental change (e.g., supplies of terrestrial and/or organic matter to the basin, hydrographic change in the bottom water, sea level change, oceanic circulation changes, or oxygenation). The indices above the $67 \mathrm{~m}$ level may not represent realistic variation in geomagnetic relative intensity. Therefore, we used an S-ratio $-0.3 \mathrm{~T}$ of less than 0.9 as a cut-off limit for useful relative paleointensity indices, so the indices above the $67 \mathrm{~m}$ level are not used in the following discussions.

The VGP latitude profile above the $38 \mathrm{~m}$ level (indicated by red open circles in Fig. 7d) exhibits stable normal polarity with three intermediate polarities at 42.4 , 54.0, and $69.2 \mathrm{~m}$ (indicated by gray arrows in Fig. 7d). The $\mathrm{NRM}_{30-50} / \mathrm{ARM}_{30-50}$ ratio above the $38 \mathrm{~m}$ level is generally higher than the overall average of 0.08 and widely fluctuates between 0.04 and 0.29 in this interval (Fig. 7e). In comparison, the VGP latitude and rockmagnetic properties remain relatively stable.

The $\mathrm{NRM}_{30-50} / \mathrm{IRM}_{30-50}$ profile was also obtained from selected specimens obtained from the Chiba composite section (Fig. $7 \mathrm{~g}$ ). This ratio shows similar variations to the $\mathrm{NRM}_{30-50} / \mathrm{ARM}_{30-50}$ ratio with the minimum value (at $1.9 \mathrm{~m}$ ) co-occurring with the $\mathrm{M}-\mathrm{B}$ boundary, a slight increase between 6 and $13 \mathrm{~m}$, and a recovery phase to full intensity at $15-25 \mathrm{~m}$. The high linear correlation coefficient between $\mathrm{NRM}_{30-50} / \mathrm{ARM}_{30-50}$ and $\mathrm{NRM}_{30-50} /$ $\mathrm{IRM}_{30-50}$ of 0.94 indicates no systematic differences between the relative paleointensity indices obtained from the Chiba composite section.

We calculated the correlations between the relative paleointensity indices and the normalizers to test for independence. The linear correlation coefficients for ARM and $\mathrm{NRM}_{30-50} / \mathrm{ARM}_{30-50}$, and SIRM and $\mathrm{NRM}_{30-50} /$ $\mathrm{IRM}_{30-50}$ are 0.44 and 0.52 , respectively (Additional file 4: Figure $\mathrm{S} 2 \mathrm{a}-\mathrm{b}$ ). These weak positive correlations imply that the relative paleointensity indices could be partially contaminated by the normalizers. On the other hand, the linear correlation coefficients for authigenic ${ }^{10} \mathrm{Be} /{ }^{9} \mathrm{Be}$ versus $\mathrm{NRM}_{30-50} / \mathrm{ARM}_{30-50}$ and $\mathrm{NRM}_{30-50} / \mathrm{IRM}_{30-50}$ are - 0.72 and -0.70 , respectively (Additional file 4: Figure $\mathrm{S} 2 \mathrm{c}-\mathrm{d}$ ). Because the cosmogenic nuclide ${ }^{10} \mathrm{Be}$ production is mainly modulated by variations in magnetospheric shielding on a millennial time scale, ${ }^{10} \mathrm{Be}$ 


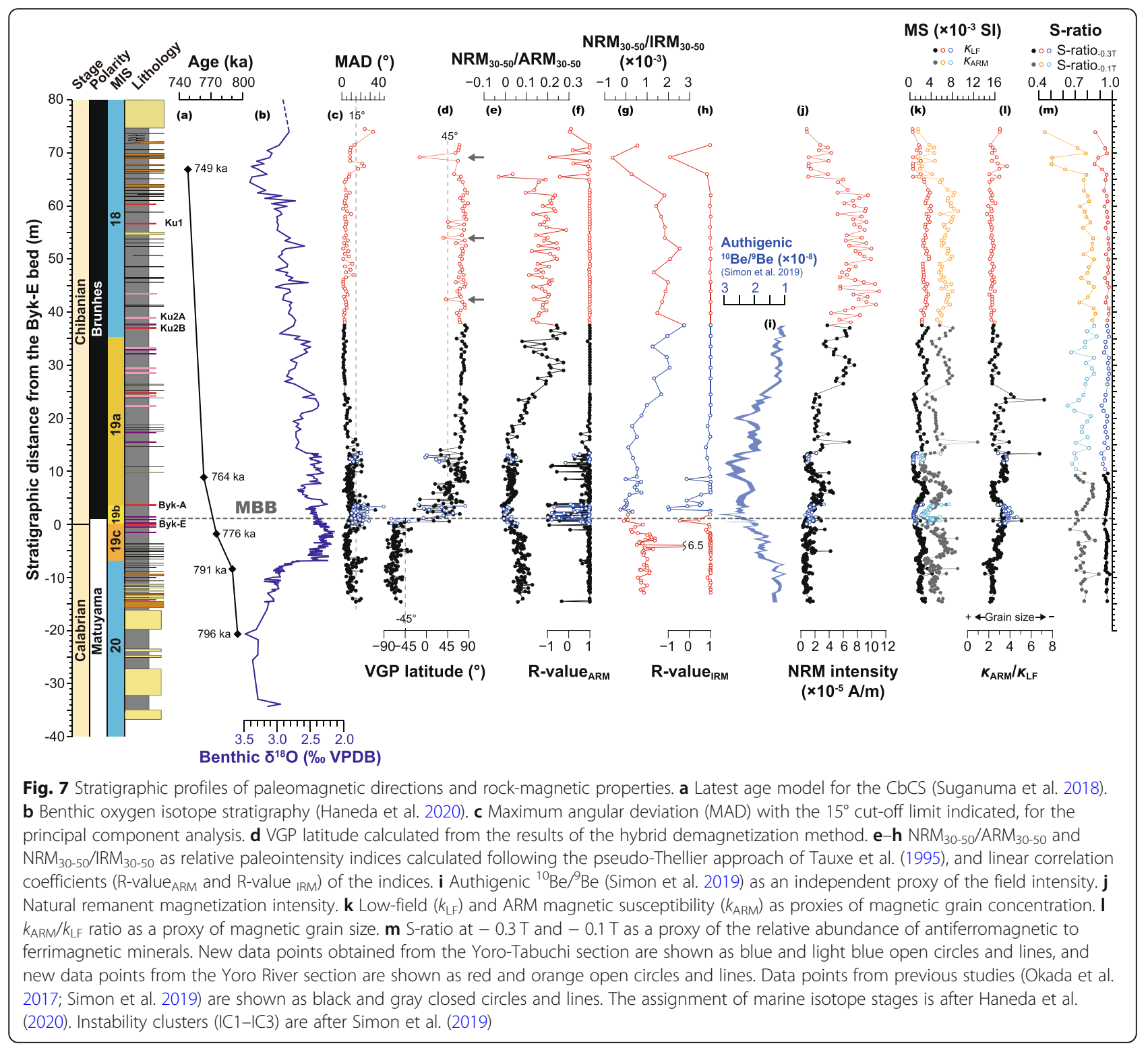

concentration records from marine sediments constitute an independent proxy of the geomagnetic dipole moment, providing that secondary depositional processes have been removed through a normalization procedure (e.g., Simon et al. 2016). The similarity of $\mathrm{NRM}_{30-50} / \mathrm{ARM}_{30-50}$ and $\mathrm{NRM}_{30-50} / \mathrm{IRM}_{30-50}$ ratios with authigenic ${ }^{10} \mathrm{Be} /{ }^{9} \mathrm{Be}$ demonstrates that the relative paleointensity from the Chiba composite section is reliable proxies for the geomagnetic field intensity variation. Therefore, we used the highresolution $\mathrm{NRM}_{30-50} / \mathrm{ARM}_{30-50}$ ratio as the best relative paleointensity index.

\subsection{Paleomagnetic directions of the lowermost part of the Yoro-Tabuchi section}

Paleomagnetic directions of the lowermost part of the Yoro-Tabuchi section were obtained from 16 levels from specimens in which the ChRM component MAD was $\leq 15^{\circ}$ (Additional file 5: Table S3). The polarity switch from a reversed polarity (VGP latitude < $45^{\circ}$ ) to a normal polarity (VGP latitude $>45^{\circ}$ ) occurs in the stratigraphic interval between 1.1 and $2.1 \mathrm{~m}$. The $\mathrm{M}-\mathrm{B}$ boundary, defined as a middle of the polarity switch interval, is located $1.6 \mathrm{~m}$ above the Byk-E tephra bed in the Yoro-Tabuchi section (Fig. 8; Table $1)$. After the polarity switch is completed, the VGP latitude largely rebounds across the Equator. The stratigraphic position of the M-B boundary and subsequent directional instability are consistent with previous paleomagnetic data from the Yanagawa section (Suganuma et al. 2015), the Chiba section (Okada et al. 2017), and the TB-2 sediment core (Hyodo et al. 2016). 


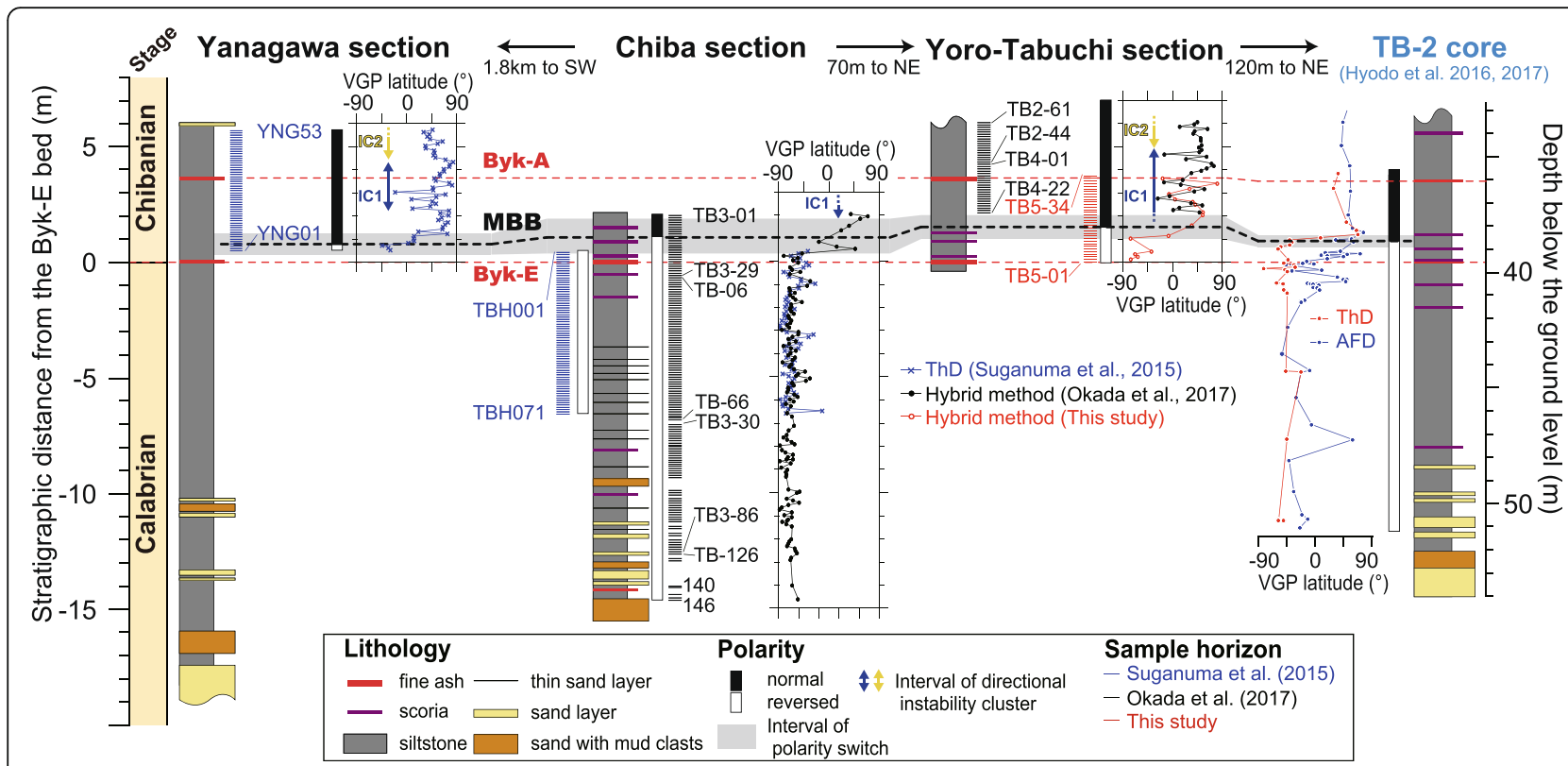

Fig. 8 Comparison of the M-B boundary observed from the Chiba composite section and the TB-2 sediment core. VGP latitudes based on thermal demagnetization in Suganuma et al. (2015) are shown as blue cross marks. VGP latitudes based on the hybrid demagnetization method are shown as black closed circles and lines (Okada et al. 2017) and red open circles and lines (this study). The TB-2 sediment core was drilled 190 $m$ northeast of the Chiba section, and VGPs obtained from the core as reported by Hyodo et al. (2016) are shown as blue closed circles and lines (AFD) and red closed circles and lines (ThD). Lithology of the TB-2 sediment core was from Hyodo et al. (2016, 2017). Blue, black, and red horizontal bars indicate the sampling level of Suganuma et al. (2015), Okada et al. (2017), and this study, respectively. Black and red dashed lines show the mid-thickness of polarity switch indicating the M-B boundary and the correlation of the volcanic ash

The $\mathrm{NRM}_{30-50} / \mathrm{ARM}_{30-50}$ ratio as a relative paleointensity index was obtained from the 16 specimens in which the ChRM component MAD was $\leq 15^{\circ}$ (Fig. 7e-f; Additional file 5: Table S3). The depletion of the relative paleointensity occurs $0.2 \mathrm{~m}$ above the Byk-E tephra bed, although the values are already lower than the average for the whole Chiba composite section (Fig. 7e). The interval of minimum relative paleointensity is observed from $3.0 \mathrm{~m}$ above the Byk-E tephra bed and is followed by subsequent directional instabilities, a phenomenon also observed in the Chiba section (Okada et al. 2017).

\subsection{Comparison of the M-B boundary in the Chiba composite section}

In this study, the M-B boundary is defined as a midpoint of the polarity switching interval from a reversed polarity (VGP latitude $<-45^{\circ}$ ) to a normal polarity (VGP latitude $>45^{\circ}$ ). An alternative definition is the stratigraphic position at which the VGP latitude $=0$. However, using this definition, the M-B boundary is identified using only two intermediate polarity data points, in the case of the Chiba composite section. Therefore, we adopt the former definition of the $\mathrm{M}-\mathrm{B}$ boundary, which is more robust.

The M-B boundary has been identified in the Yanagawa (Suganuma et al. 2015), Chiba (Okada et al. 2017), and
Yoro-Tabuchi (this study) sections of the Chiba composite section, and in the TB-2 sediment core (Hyodo et al. 2016) (Fig. 8; Table 1). The depth scale of the TB-2 sediment core was converted into the equivalent thickness scale of the Chiba composite section, using 7 tie points based on lithology and tephrostratigraphy (indicated by red solid lines in Fig. 3). The average polarity switch occurs in an interval between $0.6 \pm 0.3$ and $1.6 \pm 0.4 \mathrm{~m}(1 \sigma)$ above the Byk-E tephra bed (Table 2). The average midpoint of the polarity switch in the three sections and sediment core is $1.1 \pm 0.3 \mathrm{~m}(1 \sigma)$ above the Byk-E tephra bed (Table 2). Based on the age model of Suganuma et al. (2018), the M-B boundary is dated at $772.9 \pm 0.4 \mathrm{ka}(1 \sigma)$ and the polarity switch is completed within $1.1 \pm 0.4 \mathrm{kyrs}$ $(1 \sigma)$, although the field intensity minimum and directional instability follow it (Fig. 8; Simon et al. 2019). Assuming a potentially chronological uncertainty of $5 \mathrm{ka}$ in orbital tuning methods (Simon et al. 2019; Valet et al. 2019), the average age of the $\mathrm{M}-\mathrm{B}$ boundary in the Chiba composite section is estimated as $772.9 \pm 5.4 \mathrm{ka}(1 \sigma)$. This is consistent with the inferred ages obtained from sedimentary archives (e.g., Channell et al. 2010; Valet et al. 2019).

\subsection{Millennial-scale VGP deviation and its distribution}

The time evolution of the VGP latitude and the VGP locations in the Chiba composite section are shown in 
Table 2 Summary of the M-B boundary in the Chiba composite section

\begin{tabular}{|c|c|c|c|c|c|c|c|c|}
\hline \multirow[t]{2}{*}{ Section/Demag. method } & \multicolumn{3}{|c|}{ Stratigraphic distance from the Byk-E (m) } & \multicolumn{4}{|c|}{ Age $(k a)^{1}$} & \multirow[t]{2}{*}{ Reference } \\
\hline & Start & End & Mid-point & Start & End & Mid-point & Duration & \\
\hline Yoro-Tabuchi/hybrid & 1.07 & 2.09 & 1.58 & 772.96 & 771.79 & 772.38 & 1.17 & This study \\
\hline Yanagawa (and Chiba)/ThD & 0.35 & 1.25 & 0.80 & 773.75 & 772.73 & 773.24 & 1.02 & Suganuma et al. (2015) \\
\hline Chiba/hybrid & 0.35 & 1.85 & 1.10 & 773.75 & 772.06 & 772.91 & 1.69 & Okada et al. (2017) \\
\hline TB2 sediment core $^{2} / \mathrm{ThD}$ & 0.68 & 1.23 & 0.96 & 773.37 & 772.76 & 773.07 & 0.61 & Hyodo et al. (2016) \\
\hline Average & 0.6 & 1.6 & 1.1 & 773.5 & 772.3 & 772.9 & 1.1 & \\
\hline 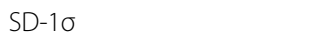 & 0.3 & 0.4 & 0.3 & 0.4 & 0.5 & 0.4 & 0.4 & \\
\hline
\end{tabular}

${ }^{1}$ Age model of Suganuma et al. (2018) is used to calculate the ages of the M-B boundary and the durations

${ }^{2}$ Depth scale of the TB-2 sediment core is converted into thickness scale in the Chiba composite section based on the lithology and tephrostratigraphy

Figs. 9, 10, and 11 alongside the relative paleointensity index $\left(\mathrm{NRM}_{30-50} / \mathrm{ARM}_{30-50}\right)$ and Be ratio-derived dipole moment (BeDM) profiles. Each temporal profile was calculated based on the latest age model of the Chiba composite section by Suganuma et al. (2018). The longest section record shown in Fig. 9 is integrated with data from the Chiba composite section and new results from the Yoro River section above $37.5 \mathrm{~m}$, which were obtained using the hybrid demagnetization method. The new record from the lowermost part of the YoroTabuchi section spans between 774.1 and $769.9 \mathrm{ka}$, which corresponds to the period from the polarity switch to the early phase of the directional instability (Fig. 10). The results of the progressive thermal demagnetization from the Chiba and Yanagawa sections show the VGP path and the VGP latitude profile between 787.1 and $767.7 \mathrm{ka}$ (Fig. 11; Suganuma et al. 2015). The VGP rebounds, which are large deviations from the north pole, after the $\mathrm{M}-\mathrm{B}$ boundary are directional instability clusters (IC1, IC2, and IC3 in Figs. 9, 10, and 11; Simon et al. 2019).

The VGP latitude profiles show millennial-scale fluctuations with intermittent depletions in relative paleointensity during periods where the BeDM was lower than its modern level (Fig. 9; Simon et al. 2019). The VGPs in the Chiba composite section prior to the $\mathrm{M}-\mathrm{B}$ boundary intermittently deviate at ca. 783,780 , and $775 \mathrm{ka}$ and mainly plot in the southeastern Pacific (Figs. 9 and 11). The VGPs then mainly shift from the Southern Hemisphere to Northern Hemisphere at ca. $773 \mathrm{ka}$ without the longitudinal preference of the VGP path suggested by Clement (1991) and Laj et al. (1991). The VGPs of the directional instability clusters are mainly located in North America and the northeastern Pacific and are scattered across Eurasia and the western Pacific (Fig. 9, 10, and 11). After the termination of IC3 at ca. 763 $\mathrm{ka}$, the VGPs is mostly stable north of $70^{\circ} \mathrm{N}$.

Millennial-scale geomagnetic field instability has been identified as a characteristic feature of the geomagnetic reversal process (e.g., Valet et al. 2012; Balbas et al.
2018; Singer et al. 2019). Valet et al. (2012) proposed the presence of three successive phases in both reversednormal and normal-reversed transitions during the last $180 \mathrm{Ma}$. Based on ten volcanic records, they suggested phasing of (i) a precursor event, (ii) a $180^{\circ}$ polarity switch, and (iii) a rebound. Based on accurate ${ }^{40} \mathrm{Ar} /{ }^{39} \mathrm{Ar}$ dating of lava flows, Singer et al. (2019) have argued that the $\mathrm{M}-\mathrm{B}$ geomagnetic reversal began in association with a large VGP deviation and field depletion at ca. $795 \mathrm{ka}$, a process recording the dominance of a non-axial dipole field, due to the collapse of the axial dipole. The interval of VGP fluctuation and depletion of the relative paleointensity at $783 \mathrm{ka}$ in the Chiba composite section are consistent with the geomagnetic field instability recorded in lava flows in Chile and Guadeloupe at ca. $784 \mathrm{ka}$ (Fig. 12; Singer et al. 2019). The VGP at ODP sites 983 and 984 in the North Atlantic shows repeatedly large fluctuation, which begins from ca. 780 and $783 \mathrm{ka}$, respectively (Fig. 12b; Channell and Guydo 2004). These VGP fluctuations observed in North Atlantic cores may correspond to the VGP fluctuations in the Chiba composite section seen from $783 \mathrm{ka}$ (Fig. 12).

Simon et al. (2019) reported the succession of large VGP deviations and low BeDM between 773.9 and $768.5 \mathrm{ka}$ in the Chiba composite section corresponding to the interval between the polarity switch and IC1. The large VGP deviations just after the M-B boundary agree with the polarity switch and subsequent rebound phases of the successive reversal as modeled by Valet et al. (2012) (Simon et al. 2019). The directional instability associated with the geomagnetic reversal terminated ca. 3 kyr prior to the field recovery at ca. $760 \mathrm{ka}$. After the field recovery, following the termination of IC3, the VGP profile is generally stable, showing only occasional deviations. Because these deviations consist of single data points and are not accompanied by large decreases in the relative paleointensity, it is reasonable to consider them as noise. The relative paleointensity after the field recovery is higher than that before the field decay, although the rock magnetic properties are relatively stable (Figs. 7 and 12). This field asymmetry across the M-B 

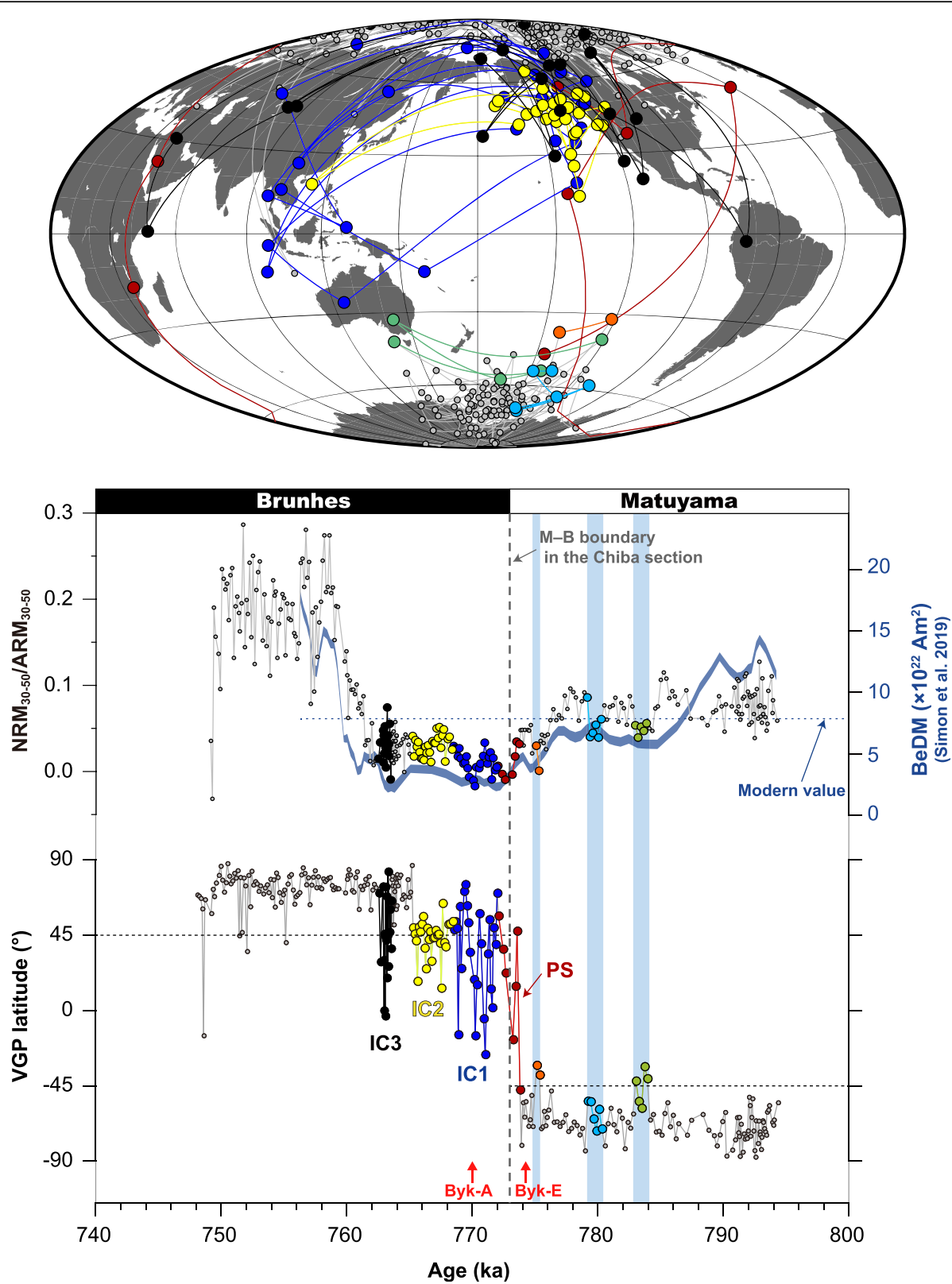

Fig. 9 VGP paths (top plot), paleomagnetic intensity indices (middle plot), and time evolution of the VGP latitude (bottom plot) of the CbCS. The integrated results of the hybrid demagnetization method from the Yoro River and Yoro-Tabuchi sections (Okada et al. 2017; Simon et al. 2019; this study). The relative paleointensity is based on the newly calculated NRM $30-50 / A R M_{30-50}$ reported in this study. The BeDM profile, shown by a blue band, is from Simon et al. (2019). Blue vertical shades and gray vertical dashed line indicate millennial-scale VGP fluctuations and the M-B boundary, respectively. Ages of the Byk-A and Byk-E tephra beds are indicated by red arrows. IC, instability cluster; PS, polarity switch

boundary is consistent with the virtual axial dipole moment series from the relative paleointensity global stacks (Fig. 12c; Valet et al. 2005; Channell et al. 2009). The paleomagnetic record of the Chiba composite section shows the full sequence of the $\mathrm{M}-\mathrm{B}$ geomagnetic reversal between 783 and $763 \mathrm{ka}$, indicating the dominant contribution of the non-axial dipole field, during the depletion of the main axial dipole, at ca. 20 kyrs interval across the M-B boundary at ca. $773 \mathrm{ka}$.

\section{Conclusions}

Paleomagnetic and rock magnetic study of the Chiba composite section located in the Boso Peninsula, Central Japan, allows reconstruction of the full sequence of the $\mathrm{M}-\mathrm{B}$ geomagnetic reversal in the interval between 794 and $748 \mathrm{ka}$. This covers the entire interval of depletion of the geomagnetic field intensity, including the polarity switch and preceding transitional phase. We have defined an average stratigraphic position and age of the 

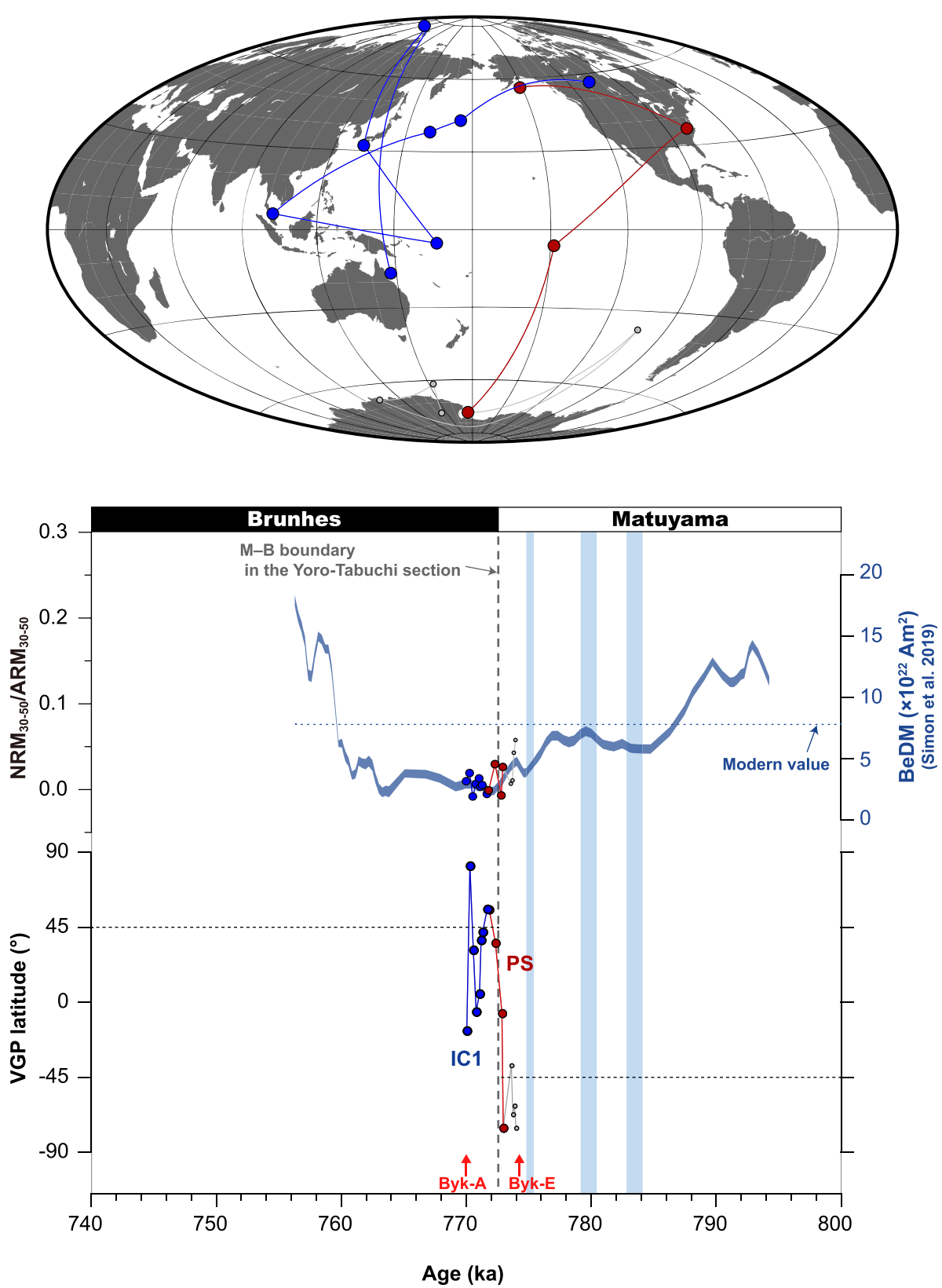

Fig. 10 VGP paths (top plot), paleomagnetic intensity indices (middle plot), and time evolution of the VGPlatitude (bottom plot) from the lowermost part of the Yoro-Tabuchi section. The relative paleointensity is based on the $\mathrm{NRM}_{30-50} / \mathrm{ARM}_{30-50}$. The BeDM profile, shown by a blue band, is from Simon et al. (2019). Blue vertical shades and gray vertical dashed line indicate millennial-scale VGP fluctuations and the M-B boundary, respectively. Ages of the Byk-A and Byk-E tephra beds are indicated by red arrows. IC, instability cluster; PS, polarity switch

M-B boundary between three (sub) sections in the Chiba composite section and a neighboring drilled core based on newly obtained and previously reported data. The VGP latitude and relative paleointensity results show a clearly defined polarity switch, with a geomagnetic field minimum, $1.6 \mathrm{~m}$ above the Byk-E tephra bed in the Yoro-Tabuchi section. This is consistent with the previously reported paleomagnetic data from the Chiba composite section. The average stratigraphic position of the $\mathrm{M}-\mathrm{B}$ boundary between the Chiba, Yoro-Tabuchi, and Yanagawa sections, and the TB-2 sediment core, lies $1.1 \pm 0.3 \mathrm{~m}(1 \sigma)$ above the Byk-E tephra bed. Accounting for uncertainty due to a $5 \mathrm{kyr}$ chronological error with the orbital tuning and a stratigraphic deviation of 0.4 kyr, the age of the M-B boundary in the Chiba composite section is estimated at $772.9 \pm 5.4 \mathrm{ka}(1 \sigma)$.

The results from the upper part of the Yoro River section exhibit homogeneous rock-magnetic properties and 

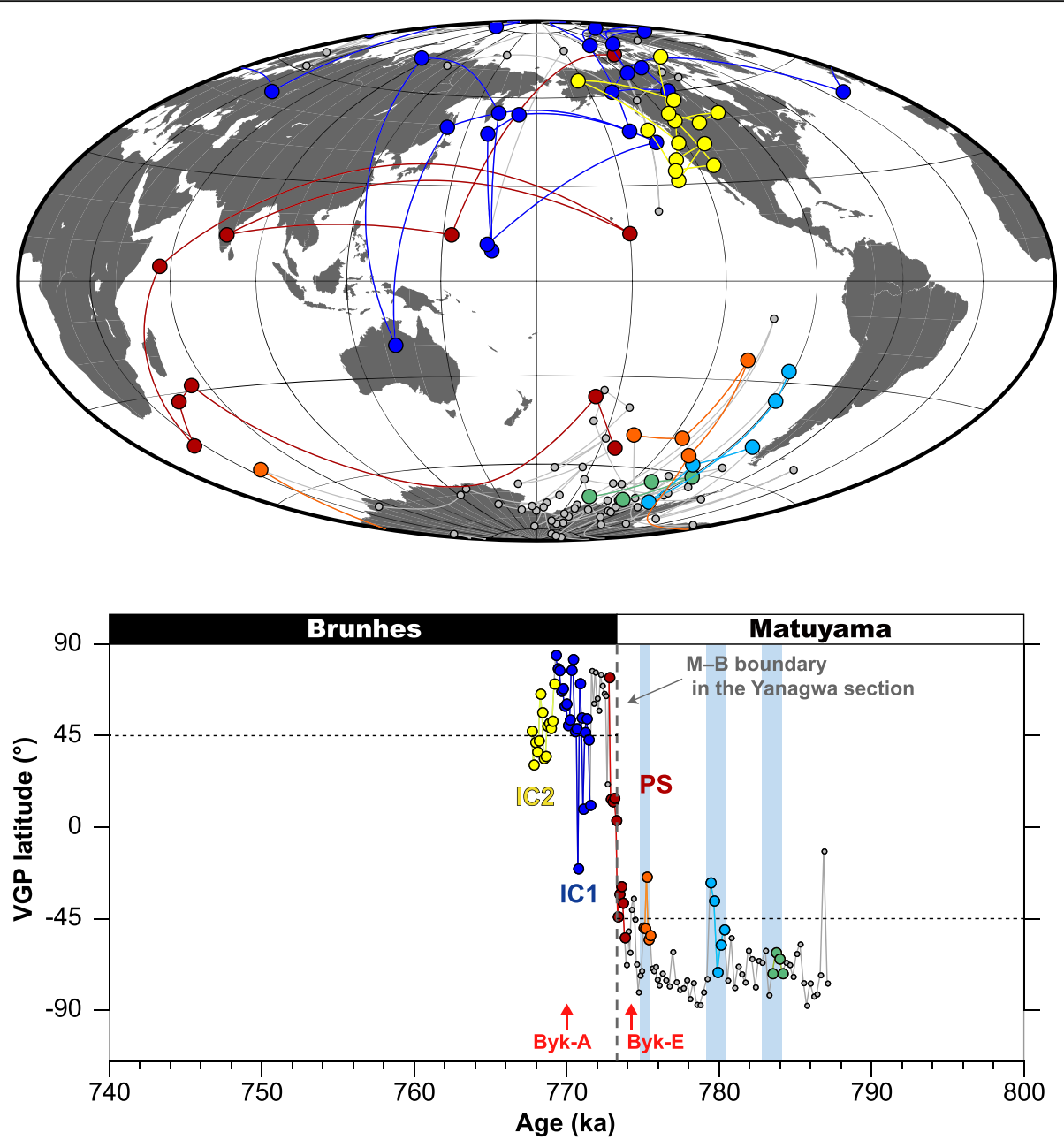

Fig. 11 VGP paths (top plot) and time evolution of the VGP latitude (bottom plot) from the Chiba and Yanagawa sections. Data are based on the progressive thermal demagnetization of Suganuma et al. (2015). The temporal profile was calculated from the most recent age model of Suganuma et al. (2018). Blue vertical shades and gray vertical dashed line indicate millennial-scale VGP fluctuations and the M-B boundary, respectively. Ages of the Byk-A and Byk-E tephra beds are indicated by red arrows. IC, instability cluster; PS, polarity switch

a higher field intensity than that before the M-B boundary, with stable normal polarity directions. Integrating the previous paleomagnetic results from the Chiba composite section shows the geomagnetic direction and relative paleointensity repeatedly deviate from the norm between ca. 783 and $763 \mathrm{ka}$. This suggests that the contribution of the non-axial dipole field was dominant during the depletion of the main axial dipole and spanned at least $20 \mathrm{kyr}$ across the polarity switch at ca. $773 \mathrm{ka}$. Our results provide a detailed and expanded sedimentary record of the $\mathrm{M}-\mathrm{B}$ geomagnetic reversal and offer valuable new information to further understand the mechanisms and dynamics of geomagnetic reversals.

\section{Supplementary information}

Supplementary information accompanies this paper at https://doi.org/10. 1186/s40645-020-00354-y.
Additional file 1: Table S1. Results of the thermal demagnetization from the Chiba and Yanagawa sections reported by Suganuma et al. (2015). Age is recalculated from the latest age model of the CbCS by Suganuma et al. (2018).

Additional file 2: Table S2. Paleomagnetic and rock magnetic results for the Yoro River and Yoro-Tabuchi sections by Okada et al. (2017), Simon et al. (2019), and this study.

Additional file 3: Figure S1. Comparison between new and previous relative paleointensity records of the $\mathrm{CbCS}$.

Additional file 4: Figure S2. Comparison of the relative paleointensity indices, normalizers, and authigenic ${ }^{10} \mathrm{Be} /{ }^{9} \mathrm{Be}$ ratio: (a) Anhysteretic remanent magnetization (ARM) intensity against $\mathrm{NRM}_{30-50} / \mathrm{ARM}_{30-50}$ ( (b) Saturation isothermal remanent magnetization (SIRM) intensity against $\mathrm{NRM}_{30-50} / \mathrm{ARM}_{30-50}$; (c) Authigenic ${ }^{10} \mathrm{Be} /{ }^{9} \mathrm{Be}$ against $\mathrm{NRM}_{30-50} / \mathrm{ARM}_{30-50 ;}$ (d) Authigenic ${ }^{10} \mathrm{Be} /{ }^{9} \mathrm{Be}$ against $\mathrm{NRM}_{30-50} / \mathrm{IRM}_{30-50}$. The result of the IRM experiment of TB40 was not used because of its large deviations.

Additional file 5: Table S3. Paleomagnetic and rock magnetic results for the lowermost part of the Yoro-Tabuchi section obtained by this study. 


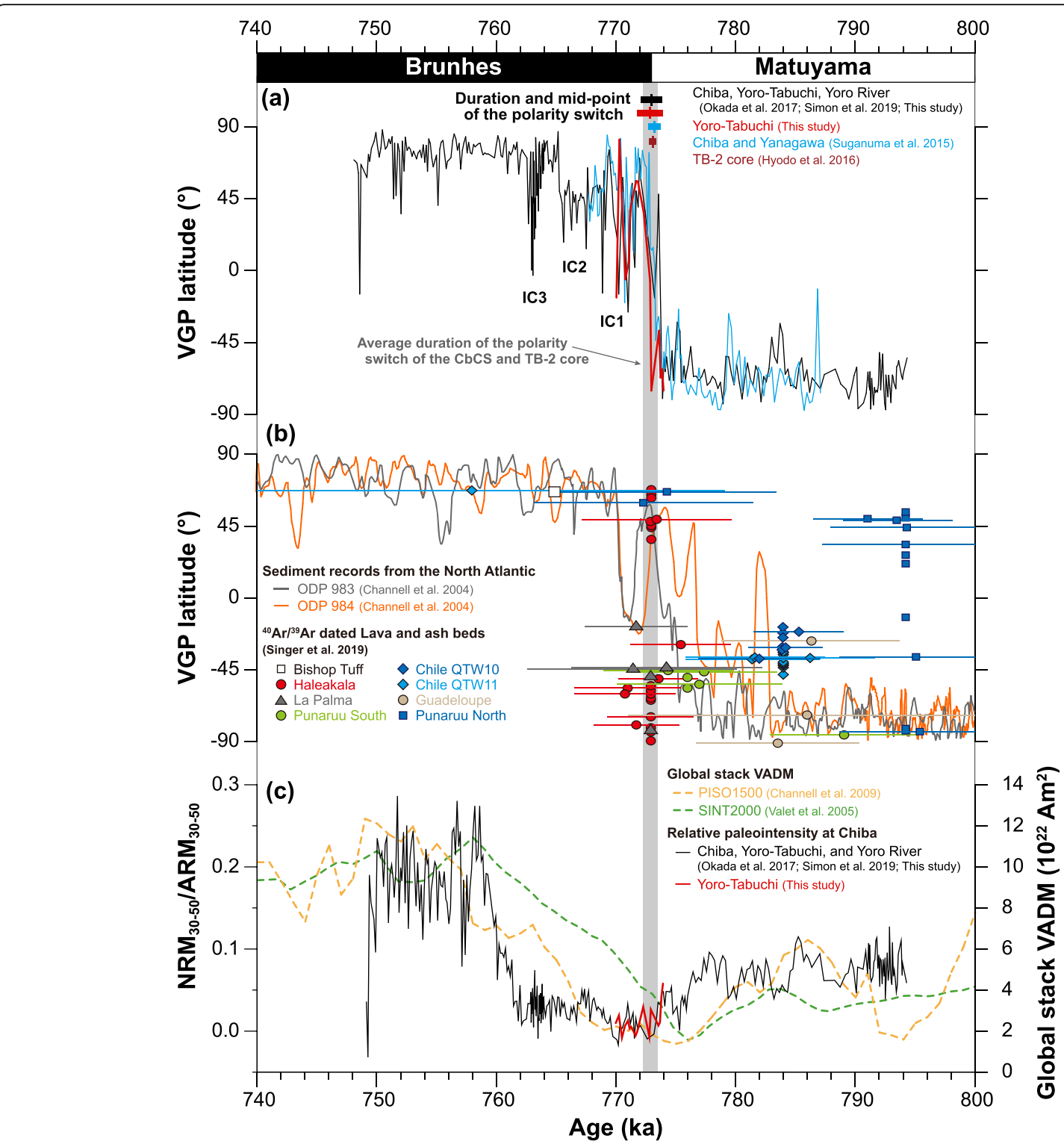

Fig. 12 Comparisons between paleomagnetic records. a VGP latitude from the Chiba composite section. The black line and cross marker are the VGP profile, and the duration and mid-point of the polarity switch from the Chiba, Yoro-Tabuchi, and Yoro River sections (Okada et al. 2017; Simon et al. 2019; this study). The red line and cross marker indicate the VGP profile and duration and mid-point of the polarity switch from the Yoro-Tabuchi section, respectively (this study). The light blue line and cross marker indicate the VGP profile and duration and mid-point of the polarity switch from the Chiba and Yanagawa sections, respectively (Suganuma et al. 2015). b VGP latitude based on marine sediment cores in the North Atlantic (green: ODP 983, orange: ODP 984 in Channell and Guydo 2004) and lavas and volcanic ash beds (Singer et al. 2019). Horizontal bars indicate chronological errors $(2 \sigma)$ of ${ }^{40} \mathrm{Ar} /{ }^{39} \mathrm{Ar}$ dating. c Proxies of field intensity. Black and red lines indicate profiles of the $\mathrm{NRM}_{30-50} / \mathrm{ARM}_{30-50}$ as the relative paleointensity index from the Chiba, Yoro-Tabuchi, and Yoro River sections (Okada et al. 2017; Simon et al. 2019; this study) and the Yoro-Tabuchi section (this study), respectively. The profiles of virtual axial dipole moment (VADM) from the global relative paleointensity stack records are indicated by orange (Channell et al. 2009) and green dashed lines (Valet et al. 2005)

\section{Abbreviations}

AF demagnetization: Alternating field demagnetization; ARM: Anhysteretic remanent magnetization; BeDM: Be ratio-derived dipole moment; CbCS: Chiba composite section; ChRM: Characteristic remanent magnetization; DRM: Detrital remanent magnetization; IC: Instability cluster; IRM: Isothermal remanent magnetization; MAD: Maximum angular deviation; M-B boundary: Matuyama-Brunhes boundary; M-B geomagnetic reversal: Matuyama-Brunhes geomagnetic reversal; MIS: Marine isotope stage; NRM: Natural remanent magnetization; ODP: Ocean Drilling Program;
SIRM: Saturation isothermal remanent magnetization; VGP: Virtual geomagnetic pole; $k_{\text {ARM: }}$ ARM susceptibility; $k_{\text {LF: }}$ Low-field magnetic susceptibility

\section{Acknowledgements}

We would like thank Yuka Shimota, Keisuke Yamamoto, and Nanako Yokokawa for collecting samples and Masayuki Hyodo for sharing the data of the TB-2 sediment core. Valuable comments made by Quentin Simon greatly improved the paper. We also greatly appreciate the kind support given by 
the Tabuchi district of Ichihara City, Chiba Prefecture, the Agency for Cultural Affairs, and the Ministry of Education, Culture, Sports, Science and Technology. We would like thank Editage (www.editage.jp) for the English language editing. This paper greatly improved by constructive comments by reviewers Mark W. Hounslow and Chuang Xuan, and editor Ryuji Tada. The sample collection within the Natural Monument site was performed with the permission and under the witness of Ichihara City, the administrator of the site.

\section{Authors' contributions}

YH carried out the experimental study and data analyses and prepared the manuscript. OM and YS proposed the topic, designed the study, assisted in the data analyses, and prepared the manuscript. TK performed the rockmagnetic analysis. All authors read and approved the final manuscript.

\section{Authors' information}

YH is a post-doctoral fellow at the Geological Survey of Japan, AIST, Japan, in present, and has belonged to National Institute of Polar Research (NIPR), Japan, during conducting the experimental study; MO is a professor at Ibaraki University, Japan; YS is an associate professor at NIPR and at the Graduate University for Advanced Studies (SOKENDAI), Japan; and TK is a master's course student at the Graduate School of Science and Engineering, Ibaraki University, Japan.

\section{Funding}

This study was supported by a JSPS KAKENHI grant (16H04068, 17H06321, and 19H00710) awarded to MO and YS, a NIPR Advanced Project (KP-7 and KP301) awarded to YS, and a Geoscience Research Grant from the Tokyo Geographical Society awarded to YH.

\section{Availability of data and materials}

Please contact author for data requests.

\section{Competing interests}

The authors declare that they have no competing interest.

\section{Author details}

'National Institute of Polar Research, 10-3 Midori-cho, Tachikawa, Tokyo 190-8518, Japan. ${ }^{2}$ Department of Earth Sciences, Ibaraki University, 2-2-1 Bunkyo, Mito, Ibaraki 310-8512, Japan. ${ }^{3}$ Present Address: Geological Survey of Japan, AIST, 1-1-1 Central 7, Higashi, Tsukuba, Ibaraki 305-8567, Japan. ${ }^{4}$ Department of Polar Science, School of Multidisciplinary Sciences, The Graduate University for Advanced Studies, SOKENDAl, Midori-cho 10-3, Tachikawa, Tokyo 190-8518, Japan.

\section{Received: 29 September 2019 Accepted: 19 July 2020}

Published online: 01 September 2020

\section{References}

Aida N (1997) Paleomagnetic stratigraphy of the type section (proposed site) for the Lower/Middle Pleistocene Boundary Kokumoto Formation. In: Kawamura M, Oka T, Kondo T (eds) Commemorative volume for Professor Makoto Kato, pp 275-282 (in Japanese with English abstract)

Amit H, Leonhardt R, Wicht J (2010) Polarity reversals from paleomagnetic observations and numerical dynamos simulations. Space Sci Rev 155:293335. https://doi.org/10.1007/s11214-010-9695-2

Aoki N (1968) Benthonic foraminifera of Kazusa Group, Boso Peninsula. Trans Proc Palaeontol Soc Japan N S 70:238-266

Balbas AM, Koppers AAP, Clark PU, Coe RS, Reilly BT, Stoner J, Konrad K (2018) Millennial-scale instability in the geomagnetic field prior to the MatuyamaBrunhes reversal. Geochem Geophys Geosyst 19:952-967. https://doi.org/10 1002/2017GC007404

Bloemendal J, King JW, Hall FR, Doh S-J (1992) Rock magnetism of late Neogene and Pleistocene deep-sea sediments: relationship to sediment source, diagenetic processes, and sediment lithology. J Geophys Res 97:4361-4375. https://doi.org/10.1029/91JB03068

Brown LL, Singer BS, Pickens JC, Jicha BR (2004) Paleomagnetic directions and ${ }^{40} \mathrm{Ar} /{ }^{39} \mathrm{Ar}$ ages from the Tatara-San Pedro volcanic complex, Chilean Andes: Lava record of a Matuyama-Brunhes precursor? J Geophys Res 109:B12101. https://doi.org/10.1029/2004JB003007
Channell JET, Guydo Y (2004) The Matuyama chronozone at ODP Site 982 (Rockhall bank): Evidence for decimeter scale magnetization lock-in depths, in Timescales of the Paelomagnetic Field. Geophys Monogr Ser 145:205-219

Channell JET, Hodell DA, Singer BS, Xuan C (2010) Reconciling astrochronological and ${ }^{40} \mathrm{Ar} /{ }^{39} \mathrm{Ar}$ ages for the Matuyama-Brunhes boundary and late Matuyama chron. Geochem Geophys Geosyst 11:Q0AA12. https://doi.org/10.1029/ 2010GC00320

Channell JET, Mazaud A, Sullivan P, Turner S, Raymo ME (2002) Geomagnetic excursions and paleointensities in the Matuyama Chron at Ocean Drilling Program Sites 983 and 984 (Iceland Basin). J Geophys Res 107:2114. https:// doi.org/10.1029/2001JB000491

Channell JET, Xuan C, Hodell DA (2009) Stacking paleointensity and oxygen isotope data for the last 1.5 Myr (PISO-1500). Earth Planet Sci Lett 283:14-23. https://doi.org/10.1016/j.epsl.2009.03.012

Cherepanova MV, Pushkar VS, Razjigaeva N, Kumai H, Koizumi I (2002) Diatom biostratigraphy of the Kazusa Group, Boso Peninsula, Honshu, Japan. Quat Res (Daiyonki-Kenkyu) 41:1-10. https://doi.org/10.4116/jaqua.41.1

Clement BM (1991) Geographical distribution of transitional VGPs: Evidence for non-zonal equatorial symmetry during the Matuyama-Brunhes geomagnetic reversal. Earth Planet Sci Lett 104:48-58. https://doi.org/10.1016/0012821X(91)90236-B

Clement BM (2004) Dependence of the duration of geomagnetic polarity reversals on site latitude. Nature 428:637-640. https://doi.org/10.1038/ nature02459

Dreyfus GB, Raisbeck GM, Parrenin F, Jouzel J, Guyodo Y, Nomade S, Mazaud A (2008) An ice core perspective on the age of the Matuyama-Brunhes boundary. Earth Planet Sci Lett 274:151-156. https://doi.org/10.1016/j.epsl. 2008.07.008

Elderfield H, Ferretti P, Greaves M, Crowhurst S, McCave IN, Hodell D, Piotrowski AM (2012) Evolution of ocean temperature and ice volume through the midPleistocene climate transition. Science 337:704-709. https://doi.org/10.1126/ science.1221294

Evans ME, Heller F (2003) Environmental Magnetism, Volume 86: Principals and Applications of Enviromagnetics. Academic Press, Amsterdam

Frank U, Nowaczyk NR (2008) Mineral magnetic properties of artificial samples systematically mixed from hematite and magnetite. Geophys J Int 175:449461. https://doi.org/10.1111/j.1365-246X.2008.03821.x

Gotton MN, Show J, Brown LL (2007) Absolute palaeointensity variation during a precursor to the Matuyama-Brunhes transition recorded in Chilean lavas. Phys Earth Planet Inter 162:61-72. https://doi.org/10.1016/j.pepi.2007.03.003

Guyodo Y, Valet JP (1999) Global changes in intensity of the Earth's magnetic field during the past 800 kyr. Nature 399:249-252. https://doi.org/10.1038/ 20420

Haneda Y, Okada M, Kubota Y, Suganuma Y (2020) Millennial-scale hydrographic changes in the northwestern Pacific during marine isotope stage 19: teleconnection with ice melt in the North Atlantic. Earth Planet Sci Lett 531: 115936. https://doi.org/10.1016/j.epsl.2019.115936

Harrison CGA (1974) The paleomagnetic record from deep-sea sediment cores. Earth Sci Rev 10:1-36. https://doi.org/10.1016/0012-8252(74)90024-5

Hartl P, Tauxe L (1996) A precursor to the Matuyama/Brunhes transition-field instability as recorded in pelagic sediments. Earth Planet Sci Lett 138:121135. https://doi.org/10.1016/0012-821X(95)00231-Z

Head MJ, Gibbard PL (2015) Early-Middle Pleistocene transitions: linking terrestrial and marine realms. Quarter Int 389:7-46. https://doi.org/10.1016/j.quaint. 2015.09.042

Head MJ, Pillans B, Farquhar S (2008) The EarlyeMiddle Pleistocene Transition: characterization and proposed quide for the defining boundary. Episodes 31: 255-259. https://doi.org/10.18814/epiiugs/2008/v31i2/014

Hyodo M, Bradák B, Okada M, Katoh S, Kitaba I, Dettman DL, Hayashi H, Kumazawa K, Hirose K, Kazaoka O, Shikoku K, Kitamura A (2017) Millennialscale northern Hemisphere Atlantic-Pacific climate teleconnections in the earliest Middle Pleistocene. Sci Rep 7:10036. https://doi.org/10.1038/s41598017-10552-2

Hyodo M, Katoh S, Kitamura A, Takasaki K, Matsushita H, Kitaba I, Tanaka I, Nara M, Matsuzaki M, Dettman DL, Okada M (2016) High resolution stratigraphy across the early-middle Pleistocene boundary from a core of the Kokumoto Formation at Tabuchi, Chiba Prefecture, Japan. Quat Int 397:16-26. https:// doi.org/10.1016/j.quaint.2015.03.031

Kanehara K, Oyama K, Ono A, Ida K, Motojima K, Ishiwada Y, Shinada Y, Makino T, Mitsunashi T, Yasukuni N (1949) Natural gas in the vicinity of Mobara, Chibaken. J Jpn Assoc Pet Technol 14:245-274. https://doi.org/10.3720/japt.14.245 
Kawai N (1951) Magnetic polarization of Tertiary rocks in Japan. J Geophys Res 56:73-79. https://doi.org/10.1029/JZ056i001 p00073

Kazaoka O, Suganuma Y, Okada M, Kameo K, Head MJ, Yoshida T, Sugaya M, Kameyama S, Ogitsu I, Nirei H, Aida N, Kumai H (2015) Stratigraphy of the Kazusa Group, Chiba Peninsula, Central Japan: an expanded and highlyresolved marine sedimentary record from the Lower and Middle Pleistocene. Quat Int 383:116-134. https://doi.org/10.1016/j.quaint.2015.02.065

Kent DV, Opdyke ND (1977) Palaeomagnetic field intensity variation recorded in a Brunhes epoch deep-sea sediment core. Nature 266:156-159. https://doi. org/10.1038/266156a0

Kirschvink JL (1980) The least-squares line and plane and the analysis of palaeomagnetic data. Geophys J R Astron Soc 62(3):699-718. https://doi.org/ 10.1111/j.1365-246X.1980.tb02601.X

Laj C, Mazaud A, Weeks R, Fuller M, Herrero-Bervera E (1991) Geomagnetic reversal paths. Nature 351:447. https://doi.org/10.1038/351447a0

Liu Q, Roberts AP, Rohling EJ, Zhu R, Sun Y (2008) Post-depositional remanent magnetization lock-in and the location of th Matuyama-Brunhes geomagnetic reversal boundary in marine and chineese loess sequences. Earth Planet Sci Lett 275:102-110

Macri P, Capraro L, Ferretti P, Scarponi D (2018) A high-resolution record of the Matuyama-Brunhes transition from the Mediterranean region: the Valle di Manche section (Calabria, Southern Italy). Phys Earth Planet Inter 278:1-15. https://doi.org/10.1016/j.pepi.2018.02.005

Ménabréaz L, Bourlès DL, Thouveny N (2012) Amplitude and timing of the Laschamp geomagnetic dipole low from the global atmospheric 10Be overpro-duction: contribution of authigenic ${ }^{10} \mathrm{Be} /{ }^{\circ} \mathrm{Be}$ ratios in west equatorial Pacific sediments. J Geophys Res 117:B11101

Mitsunashi T (1954) Geology of the southern distinct of Kinadayama, Boso Peninsula-Notes on the extension of rock facies in time and space. J Geol Soc Jpn 60:461-472 (in Japanese with English abstract)

Mitsunashi T, Yasukuni N, Shinada Y (1959) Stratigraphical section ofthe Kazusa Group along the shores of the Rivers Yoro and Obitsu. Bull Geol Surv Jpn 10: 83-98 (in Japanese, with English abstract)

Nakagawa H, Niitsuma N, Hayasaka I 1969) Late Cenozoic geomagnetic chronology on the Boso Peninsula. J Geol Soc Jpn 73:267-281 (in Japanese, with English abstract). https://doi.org/10.5575/geosoc.75.267

Nakajima T (1978) Sedimentary environment of flysch sediments in the Boso Peninsula, Japan -relationship between flysch and its marginal facies of the Kiwada, Kurotaki and Anno Formations. J Geol Soc Jpn 84:645-660 (in Japanese with English abstract)

Niitsuma N (1971) Detailed study of the sediments recording the MatuyamaBrunhes geomagnetic reversal. Tohoku Univ Sci Rep 2nd Ser (Geol) 43:1-39

Niitsuma N (1976) Magnetic stratigraphy in the Boso Peninsula. J Geol Soc J.pn 82:163-181 (in Japanese with English abstract)

Nishida N, Kazaoka O, Izumi K, Suganuma Y, Okada M, Yoshida T, Ogitsu I, Nakazato H, Kameyama S, Kagawa A, Morisaki M, Nirei N (2016) Sedimentary processes and depositional environments of a continuous marine succession across the Lower-Middle Pleistocene boundary: Kokumoto Formation, Kazusa Group, central Japan. Quat Int 397:3-15. https://doi.org/10.1016/.quaint.2015.06.045

Oda H, Xuan C (2014) Deconvolution of continuous paleomagnetic data from passthrough magnetometer: a new algorithm to restore geomagnetic and environmental information based on realistic optimization. Geochem Geophys Geosyst 15:3907-3924. https://doi.org/10.1002/2014GC005513

Oda M (1977) Planktonic foraminiferal biostratigraphy of the Late Cenozoic sedimentary sequences, Central Honshu, Japan. In: Science reports of Tohoku University, 2nd series (geology), vol 48, pp 1-72

Okada M, Niitsuma N (1989) Detailed paleomagnetic records during the Brunhes-Matuyama geomagnetic reversal and a direct determination of depth lag for magnetization in marine sediments. Phys Earth Planet Inter 56: 133-150. https://doi.org/10.1016/0031-9201(89)90043-5

Okada M, Suganuma Y, Haneda Y, Kazaoka O (2017) Paleomagnetic direction and paleointensity variations during the Matuyama-Brunhes polarity transition from a marine succession in the Chiba composite section of the Boso Peninsula, central Japan. Earth Planets Space 69:45. https://doi.org/10.1186/ s40623-017-0627-1

Olson PL, Glatzmaier GA, Coe RS (2011) Complex polarity reversals in a geodynamo model. Earth Planet Sci Lett 304:168-179. https://doi.org/10. 1016/j.epsl.2011.01.031

Opdyke ND, Glass B, Hays JD, Foster J (1966) Paleomagnetic study of sediments in a revolutionary method of dating events in Earth's history. Science 154 349-357. https://doi.org/10.1126/science.154.3747.349
Philippe ÉGH, Valet JP, St-Onge G, Thevarasan A (2018) Are paleomagnetic records from U-channels appropriate for studies of reversals and excursions? Geochem Geophys Geosyst 19:4130-4142. https://doi.org/10.1029/ 2018GC007803

Pickering KT, Souter C, Oba T, Taira A, Schaaf M, Platzman E (1999) Glacio-eustatic control on deep-marine clastic forearc sedimentation, Pliocene-midPleistocene(c. 1180imentka)Kazusa Group. SE Japan. J Geol Soc Lond 156: 125-136. https://doi.org/10.1144/gsjgs.156.1.0125

Raisbeck GM, Yiou F, Cattani O, Jouzel J (2006) ${ }^{10}$ Be evidence for the MatuyamaBrunhes geomagnetic reversal in the EPICA Dome C ice core. Nature 443:8284. https://doi.org/10.1038/nature05266

Roberts AP, Tauxe L, Heslop D (2013) Magnetic paleointensity stratigraphy and high-resolution Quaternary geochronology: successes and future challenges. Quat Sci Rev 61:1-16. https://doi.org/10.1016/j.quascirev.2012.10.036

Sagnotti L, Giaccio B, Liddicoat JC, Nomade S, Renne PR, Scardia G, Sprain CJ (2016) How fast was the Matuyama-Brunhes geomagnetic reversal? A new subcentennial record from the Sulmona Basin, central Italy. Geophys J Int 204:798-812. https://doi.org/10.1093/gji/ggv486

Sagnotti L, Scardia G, Giaccio B, Liddicoat JC, Nomade S, Renne PR, Sprain C (2014) Extremely rapid directional change during Matuyama-Brunhes geomagnetic polarity reversal. Geophys J Int 199:1110-1124. https://doi.org/ 10.1093/gji/ggu287

Sato T, Takayama T, Kato M, Kudo T, Kameo K (1988) Calcareous microfossil biostratigraphy of the uppermost Cenozoic formations distributed in the coast of the Japan Sea, part 4: conclusion. J Jpn Assoc Pet Technol 53:474491 (in Japanese with English abstract)

Satoguchi Y, Nagahashi Y (2012) Tephrostratigraphy of the Pliocene to Middle Pleistocene Series in Honshu and Kyushu Islands, Japan. Island Arc 21:149169. https://doi.org/10.1111/j.1440-1738.2012.00816.x

Shin JY, Yu Y, Kim W (2019) Wavelet-based verification of a relative paleointensity record from the North Pacific. Earth Planet Space 71:88. https://doi.org/10. 1186/s40623-019-1067-x

Shinada Y, Maki S, Takada Y, Omori E (1951) Investigation of iodic brine waters in the vicinity of Kuniyoshi-machi, Chiba Pref. J Jpn Assoc Pet Technol 16:312326

Simon Q, Bourlès DL, Thouveny N, Horng CS, Valet JP, Bassinot F, Choy S (2018b) Cosmogenic signature of geomagnetic reversals and excursions from the Réunion event to the Matuyama-Brunhes transition (0.7-2.14 Ma interval). Earth Planet Sci Lett 482:510-524. https://doi.org/10.1016/j.epsl.2017.11.021

Simon Q, Suganuma Y, Okada M, Haneda Y, ASTER team (2019) High-resolution ${ }^{10} \mathrm{Be}$ and paleomagnetic recording of the last polarity reversal in the Chiba composite section: Age and dynamics of the Matuyama-Brunhes transition. Earth Planet Sci Lett 519:92-100. https://doi.org/10.1016/j.epsl.2019.05.004

Simon Q, Thouveny N, Bourlès DL, Bassinot F, Savranskaia T, Valet JP (2018a) Increased production of cosmogenic ${ }^{10} \mathrm{Be}$ recorded in oceanic sediment sequences: information on the age, duration, and amplitude of the geomagnetic dipole moment minimum over the Matuyama-Brunhes transition. Earth Planet Sci Lett 489:191-202. https://doi.org/10.1016/j.epsl. 2018.02.036

Simon Q, Thouveny N, Bourlès DL, Valet JP, Bassinot F, Ménabréaz L, Guillou V, Choy S, Beaufort $L$ (2016) Authigenic ${ }^{10} \mathrm{Be} /{ }^{9} \mathrm{Be}$ ratio signatures of the cosmogenic nuclide production linked to geomagnetic dipole moment variation since the Brunhes/Matuyama boundary. J Geophys Res Solid Earth 121:7716-7741. https://doi.org/10.1002/2016JB013335

Singer BS, Hoffman KA, Coe RS, Brown LL, Jicha BR, Pringle MS, Chauvin A (2005) Structural and temporal requirements for geomagnetic field reversal deduced from lava flows. Nature 434:633-636. https://doi.org/10.1038/ nature03431

Singer BS, Jicha BR, Mochizuki N, Coe RS (2019) Synchronizing volcanic, sedimentary, and ice core records of Earth's last magnetic polarity reversal. Sci Adv 5:eaaw4621. https://doi.org/10.1126/sciadv.aaw4621

Suganuma Y, Haneda Y, Kameo K, Kubota Y, Hayashi H, Itaki T, Okuda M, Head MJ, Sugaya M, Nakzato H, Igarashi A, Shikoku K, Hongo M, Watanabe M, Satoguchi Y, Takeshita Y, Nishida N, Izumi K, Kawamura K, Kawamata M, Okuno J, Yoshida T, Ogitsu I, Yabusaki H, Okada M (2018) Paleoclimatic and Paleoceanographic records of Marine Isotope Stage 19 at the Chiba composite section, central Japan: A reference for the Early-Middle Pleisotocene boundary. Quat Sci Rev 191:406-430. https://doi.org/10.1016/j. quascirev.2018.04.022

Suganuma Y, Okada M, Horie K, Kaiden H, Takehara M, Senda R, Kimura J, Kawamura K, Haneda Y, Kazaoka O, Head MJ (2015) Age of Matuyama- 
Brunhes boundary constrained by U-Pb zircon dating of a widespread tephra. Geology 43:491-494. https://doi.org/10.1130/G36625.1

Suganuma Y, Okuno J, Heslop D, Roberts AP, Yamazaki T, Yokoyama Y (2011) Post-depositional remanent magnetization lock-in for marine sediments deduced from 10 Be and paleomagnetic records through the MatuyamaBrunhes boundary. Earth Planet Sci Lett 311:39-52. https://doi.org/10.1016/j. epsl.2011.08.038

Suganuma Y, Yamazaki T, Kanamatsu T, Hokanishi N (2008) Relative paleointensity record during the last $800 \mathrm{ka}$ from the equatorial Indian Ocean: implication for relationship between inclination and intensity variations. Geochem Geophys Geosyst 9:Q02011. https://doi.org/10.1029/2007GC001723

Suganuma Y, Yokoyama Y, Yamazaki T, Kawamura K, Horng CS, Matsuzaki H (2010) ${ }^{10} \mathrm{Be}$ evidence for delayed acquisition of remanent magnetization in marine sediments: implication for a new age for the Matuyama-Brunhes boundary. Earth Planet Sci Lett 296:443-450. https://doi.org/10.1016/j.epsl. 2010.05.031

Takeshita Y, Matsushima N, Teradaira H, Uchiyama T, Kumai H (2016) A marker tephra bed close to the Middle Pleistocene boundary: distribution of the Ontake-Byakubi tephra in central Japan. Quat Int 397:27-38. https://doi.org/ 10.1016/j.quaint.2015.03.054

Tauxe L (1993) Sedimentary Records of Relative Paleointensity of the Geomagnetic-Field - Theory and Practice. Rev Geophys 31:319-354. https:// doi.org/10.1029/93RG01771

Tauxe L, Pick T, Kok YS (1995) Relative paleointensity in sediments: a PseudoThellier approach. Geophys Res Lett 22:2885-2888. https://doi.org/10.1029/ 95GL03166

Tauxe L, Shackleton NJ (1994) Relative paleointensity records from the OntongJava Plateau. Geophys J Int 117:769-782. https://doi.org/10.1111/j.1365-246X. 1994.tb02469.x

Tsuji T, Miyata Y, Okada M, Mita I, Nakagawa H, Sato Y, Nakamizu M (2005) Highresolution chronology of the lower Pleistocene Otadai and Umegase Formations of the Kazusa Group, Boso Peninsula, central Japan: chronostratigraphy of the JNOC TR-3 cores based on oxygen isotope, magnetostratigraphy and calcareous nannofossil. J Geol Soc Jpn 111:1-20 (in Japanese with English abstract)

Tsunakawa H, Okada M, Niitsuma N (1995) About 100 year Directional variation in the Matuyama-Brunhes transitional field inferred from the sedimentary records in the Boso Peninsula, Japan. J Geomagn Geoelectr 47:337-345. https://doi.org/10.5636/jgg.47.337

Tsunakawa H, Okada M, Niitsuma N (1999) Further application of the deconvolution method of post-depositional DRM to the precise record of the Matuyama-Brunhes reversal in the sediments from the Boso Peninsula, Japan. Earth Planets Space 51:169-173. https://doi.org/10.1186/BF03352221

Valet JP (2003) Time variations in geomagnetic intensity. Rev Geophys 41:1004. https://doi.org/10.1029/2001RG000104

Valet JP, Bassinot F, Bouilloux A, Bourlès D, Nomade S, Guillou V, Lopes F, Thouveny N, Dewilde F (2014) Geomagnetic, cosmogenic and climatic changes across the last geomagnetic reversal from Equatorial Indian Ocean sediments. Earth Planet Sci Lett 397:67-79. https://doi.org/10.1016/.jepsl.2014. 03.053

Valet JP, Bassinot F, Simon Q, Savranskaia T, Thouveny N, Bourlés DL, Villedieu A (2019) Constraining the age of the last geomagnetic reversal from geochemical and magnetic analyses of Atlantic, Indian, and Pacific Ocean sediments. Earth Planet Sci Lett 506:323-331. https://doi.org/10.1016/j.epsl. 2018.11.012

Valet JP, Fournier A (2016) Deciphering records of geomagnetic reversals. Rev Geophys 54. https://doi.org/10.1002/2015RG000506

Valet JP, Fournier A, Courtillot V, Herrero-Bervera E (2012) Dynamical similarity of geomagnetic field reversals. Nature 490:89-94. https://doi.org/10.1038/ nature 11491

Valet JP, Meynadier L, Guyodo Y (2005) Geomagnetic dipole strength and reversal rate over the past two million years. Nature 435:802-805. https://doi. org/10.1038/nature03674

Valet JP, Meynadier L, Simon Q, Thouveny N (2016) When and why sediments fail to record the geomagnetic field during polarity reversals? Earth Planet Sci Lett 453:96-107. https://doi.org/10.1016/j.epsl.2016.07.055

Yamazaki T (1999) Relative paleointensity of the geomagnetic field during Brunhes Chron recorded in North Pacific deep-sea sediment cores: orbital influence? Earth Planet Sci Lett 169:23-35. https://doi.org/10.1016/S0012$821 \times(99) 00064-3$
Yamazaki T, Abdeldayem AL, Ikehara K, (2003) Rock-magnetic changes with reduction diagenesis in Japan Sea sediments and preservation of geomagnetic secular variation in inclination during the last 30,000 years. Earth, Planets and Space 55 (6):327-340.

Yamazaki T (2008) Magnetostatic interactions in deep-sea sediments inferred from first-order reversal curve diagrams: Implications for relative paleointensity normalization. Geochem Geophys Geosyst 9:Q02005. https:// doi.org/10.1029/2007GC001797

Yamazaki T, Ikehara M (2012) Origin of magnetic mineral concentration variation in the Southern Ocean. Paleoceanography 27:PA2206. https://doi.org/10. 1029/2011 pa002271

Yamazaki T, Kanamatsu T (2007) A relative paleointensity record of the geomagnetic field since 1.6 Ma from the North Pacific. Earth Planet Space 59: 785-794. https://doi.org/10.1186/BF03352741

Zijderveld JDA (1967) A.C. demagnetization of rocks: analysis of result. In: Collinson DW, Creer KM, Runcorn SK (eds) Methods in paleomagnetism. Elsevier, New York, pp 254-286

\section{Publisher's Note}

Springer Nature remains neutral with regard to jurisdictional claims in published maps and institutional affiliations.

\section{Submit your manuscript to a SpringerOpen ${ }^{\circ}$ journal and benefit from:}

- Convenient online submission

- Rigorous peer review

- Open access: articles freely available online

- High visibility within the field

- Retaining the copyright to your article

Submit your next manuscript at $\boldsymbol{\nabla}$ springeropen.com 